\title{
Influence of country-specific determinants on performance of small and medium enterprises of Europe
}

\author{
Byubyukan Kushubakova \\ Candidate of economic sciences (Ph.D.), Lecturer \\ ORCID \\ E-mail: kushubakova@yandex.ru \\ Department of Economic and Legal Security \\ Bashkir State University, Ufa, Russia

\section{Sofia Strakhova} \\ Analysis and Reporting Specialist \\ $\underline{\text { ORCID }}$ \\ E-mail: sofya.strakhova@yandex.ru \\ Nutricia Danone, OOO, the Moscow Region, Russia
}

Journal of Corporate Finance Research, Vol. 14, No. 4, pp. 61-89 (2020)

DOI: https://doi.org/10.17323/j.jcfr.2073-0438.14.4.2020.61-89

Received 15 October 2020 | Peer-reviewed 23 October 2020 | Accepted 24 October 2020 


\section{Influence of country-specific determinants on performance of small and medium enterprises of Europe}

\section{Abstract}

A lot of obstacles stand in the way of small and medium enterprises formation. One of the first ones is an external financing gap in the majority of Central and Eastern Europe countries. Considering the totality of problems identified by entrepreneurs one may notice that the major part of them is made up of external impact factors.

The purpose of the present study is revealing the influence of country-specific determinants on performance of small and medium enterprises in 24 European countries. The research analyzed 54,512 SME within the period of 2013 to 2017.

The practical value of the research consists in the fact that its results may be useful for: governmental agencies in optimizing the existing small and medium enterprises support programs, emergent entrepreneurs when choosing the country to start up their business and for a better understanding of their environment, management when choosing the ways of entrepreneurship geographical expansion.

The applied importance of this paper consists in defining the most significant country-specific determinants of SME performance.

The regression analysis results show that the majority of small and medium enterprises from the point of view of macroeconomic and political conditions exist "in spite of, not thanks to something". We also identified a negative relation between the government machinery efficiency as such and its efficiency in relation to SME which means that a lot of effort is necessary for improvement in this sphere. Analysis of the difference between developed and emerging countries revealed a slight positive influence of corruption on SME's return on assets in emerging countries. Northern Europe is considered to be the friendliest region for small and medium enterprises while Eastern Europe is the least favourable one.

Key words: SMB, SME, ROA, performance, external determinants, corruption JEL classification: G32, G41, K00, O30 


\section{Introduction}

Small and medium enterprises (SME or small and medium business - SMB) are one of the drivers of economic and scientific-and-technological advance and the main job creator in all economic sectors. Through the whole SME life cycle a lot of factors (external and internal ones) influence various aspects of the small business's life. These factors may have a direct or indirect impact.

There is a series of studies dedicated to influence of external factors on various spheres of SME functioning. They range from the studies dedicated to analysis of influence of country-specific determinants on financial leverage [1; 2], working capital [3] to psychological and management studies - external influence on personality indicators of entrepreneurs as factors of small business success $[4 ; 5]$.

Although the previous studies have made an unquestionable contribution to understanding of the factors which influence SME performance the papers in this field are still in the course of development. The issue of the extent of influence of a variety of country-specific factors on SME performance and development is still pending because a lot of previous research in this field are focused mainly on large enterprises.

The majority of studies use indexes and poll numbers (generally available ones as well as the ones developed and conducted by the author) to assess influence of external factors on the main indicators. In most cases the papers study influence of indirect factors of the external environment. It is caused by an absence of or incomplete summary information available in the field in question. For example, in Russia there is no unified database which records government expenditure on financing of SME development assistance. While the federal budget data is published on a regular basis the information on Russian constituent entities, municipal entities and various types of small and medium enterprises' support (in monetary terms) is not aggregated. This is another obstacle in the way of research in this field.

In general, the existing information on the factors which influence success of SCE activities is fragmented and this theme still needs elaboration due to insufficiency of theoretical basics [6;7] and data which could be used for research.

\section{Literature Review}

\section{Distinctive Features of SME in Developed and Emerging Countries}

There are special established criteria in various countries according to which enterprises are classified as micro, small and medium ones. Fundamentally, they are defined on the basis of two criteria: revenue and stuff headcount. This paper deals with European countries. For this reason in order to simplify data processing and classify the companies in the sample we used the criteria established the European Commission for all European countries (instead of individual criteria for each country). Table 1 represents an example of difference in SME classification between the European Commission criteria and the ones of Federal Law No. 209-FZ On Development of Small and Medium-Sized Entrepreneurship in the Russian Federation.

For today the fact that it is necessary to develop and support small enterprises is beyond dispute. Comparison of the small business' role in growth of economic and socially important indicators (GDP, export, employment of population etc.) may serve as evidence. When considering the SMB status indicators [8] one may emphasize that European countries show better results than Russia, but lower than Israel or Japan (Figure 1).

Table 1. SME Classification Criteria ${ }^{1,2}$

Russia $^{3}$

\section{European countries}

$\begin{array}{lll}\text { Revenue, } & \text { Stuff headcount } & \text { Revenue, } \\ \text { million Euro } & \text { million Euro } & \text { Stuff headcount }\end{array}$

\begin{tabular}{|c|c|c|c|c|}
\hline Medium & $10-25$ & $101-250$ & $10-50$ & $50-250$ \\
\hline Small & $1.5-10$ & $15-100$ & $2-10$ & $10-50$ \\
\hline Micro & $<1.5$ & $<15$ & $<2$ & $<10$ \\
\hline
\end{tabular}

\footnotetext{
${ }^{1}$ Federal Law No. 209-FZ On Development of Small and Medium-Sized Entrepreneurship in the Russian Federation.

${ }^{2}$ European Commission. What is an SME? URL: http://ec.europa.eu/growth/smes/business-friendly-environment/sme-definition_en

${ }^{3}$ These limitations are changed at the legislative level each five years.
} 
Figure 1. Indicators of the Status of Small and Medium Business [8]
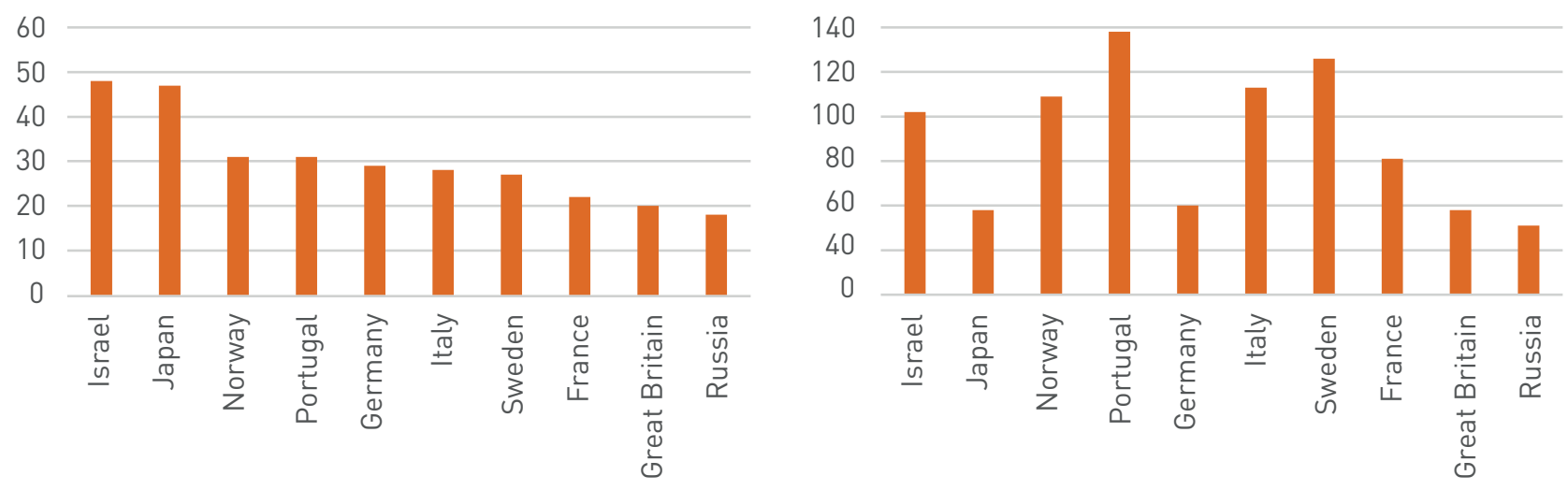

Figure 2. Global Entrepreneurship Monitor of the Population Aged 18-64, \% [11]
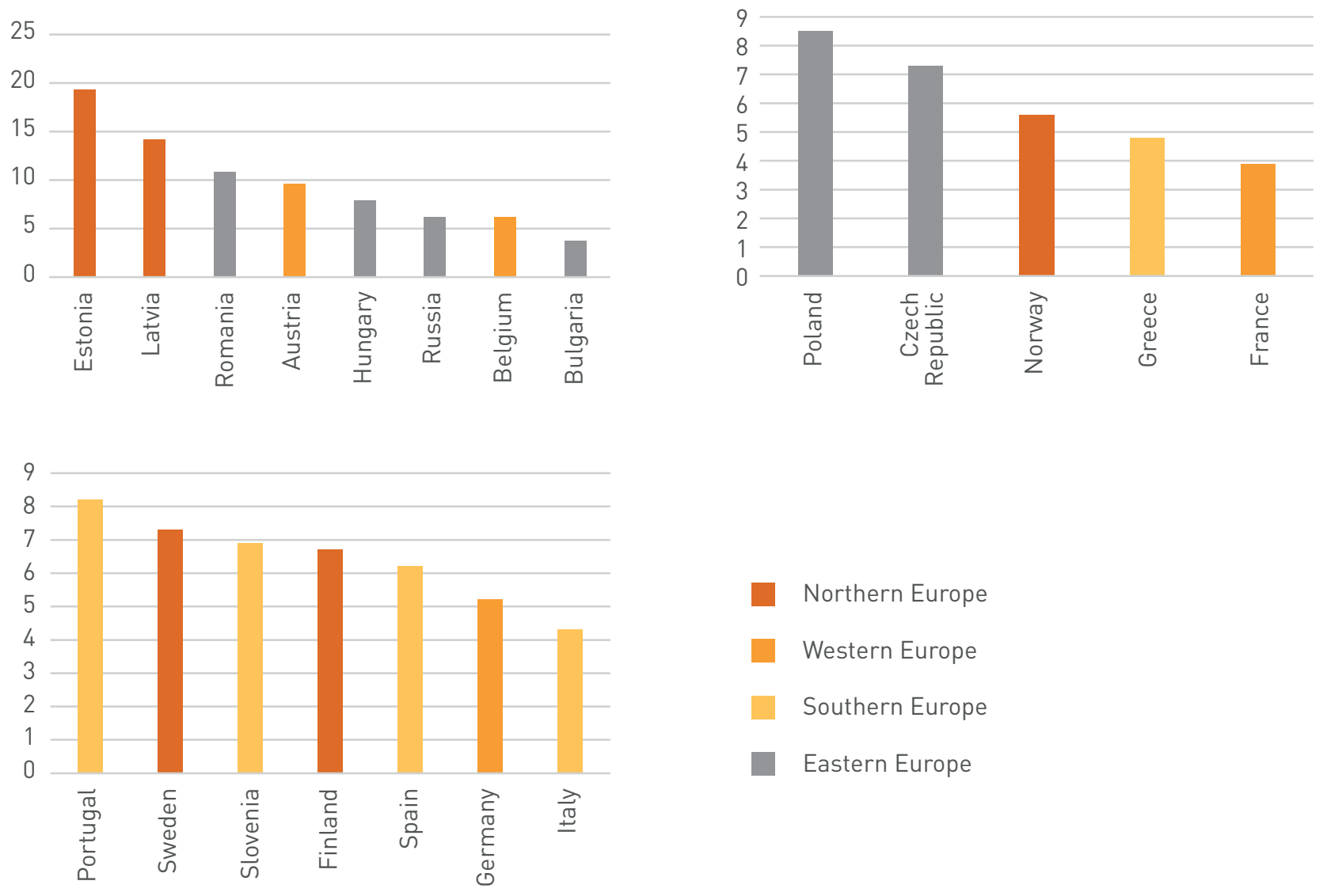

The data offered by the Global Entrepreneurship Monitor (GEM) based on annual polls does not provide an understanding of the general trend for increase of business activity. However, Eastern Europe is the most advanced region in terms of this indicator (Figure 2). In accordance with GERA report for 2017 it is mainly due to the crisis [9]. Russian analysts agree with it, they say that increasingly more people are forced to go into business because they have lost their jobs.

There are ratings which provide a full assessment of favourability of conditions for business. The annual ones are comprised of Ease of Doing Business (compiled by the World Bank on the basis of annual data) and Best Countries for Business (published by Forbes).

Ease of Doing Business is the rating which highest ranking is indicative of the quality and simplicity of business governing in the country as well as a high level of property rights protection (the regulatory environment is more favourable for incorporation and business development). Since 2001 over 800 scientific works have used this rating data (starting a business, dealing with construction permits, getting electricity, registering property, getting credits, protecting minority investors, paying taxes, trading across borders, enforcing contract, resolving insolvency). The results of the researches show a strong interrelation between economic growth and improvement of the conduct of business rules. 
Best Countries for Business is the rating compiled for 12 previous years by the American Financial and Economics Magazine Forbes. This rating is based on 15 factors: property rights, innovation, taxes, technology, corruption, infrastructure, market size, political risk, quality of life, workforce, freedom (trade, monetary and personal). Unlike the rating of the World Bank the methodology of index calculation in this ranking was changed significantly. That is why it is impossible to determine the general trend of ease of doing business for each country in dynamics for the whole time of the rating existence.

On the basis of analysis of these ratings for five years one can indicate the following general trend: the top positions are occupied by Northern European countries, Western Europe follows them, Southern European countries are spread across the sample in a random way and the majority of Eastern European countries are at the bottom of the rating (Table 2).

There are a lot of obstacles in the way of SMB formation and development. One of the first obstacles in the majority of Central and Eastern Europe countries is external financing gap [13]. See detailed information on the external financing gap of SME in various countries in the reports by the European Investment Bank. They also state a review of countries' economic status, evaluation of demand and offer of SMB financing.

Table 2. Forbes rating Best Countries for Business in $2018^{4}$

\begin{tabular}{|c|c|c|}
\hline Country & Code & $\begin{array}{l}\text { Forbes rating } \\
\text { position } \star *\end{array}$ \\
\hline Great Britain & GBR & 1 \\
\hline Sweden & SWE & 2 \\
\hline The Netherlands & NLD & 4 \\
\hline Denmark & DNK & 7 \\
\hline Ireland & IRL & 11 \\
\hline Finland & FIN & 13 \\
\hline Germany & DEU & 14 \\
\hline Norway & NOR & 15 \\
\hline Spain & ESP & 18 \\
\hline Belgium & BEL & 20 \\
\hline France & FRA & 21 \\
\hline Austria & AUT & 22 \\
\hline Luxembourg & LUX & 23 \\
\hline
\end{tabular}

\begin{tabular}{|c|c|c|}
\hline Country & Code & $\begin{array}{l}\text { Forbes rating } \\
\text { position }\end{array}$ \\
\hline Portugal & PRT & 25 \\
\hline Iceland & ISL & 26 \\
\hline Lithuania & LTU & 27 \\
\hline Estonia & EST & 28 \\
\hline Czech Republic & CZE & 29 \\
\hline Italy & ITA & 30 \\
\hline Slovenia & SVN & 31 \\
\hline Poland & POL & 34 \\
\hline Latvia & LVA & 36 \\
\hline Slovakia & SK & 38 \\
\hline Hungary & HUN & 40 \\
\hline Romania & ROU & 41 \\
\hline Greece & GRC & 42 \\
\hline Bulgaria & BGR & 46 \\
\hline Russia & RUS & 55 \\
\hline Ukraine & UKR & 77 \\
\hline $\begin{array}{l}\text { Northern } \mathrm{E} \\
\text { Western Eu } \\
\text { Southern E } \\
\text { Eastern Eu }\end{array}$ & $\begin{array}{l}\text { pe } \\
\text { pe } \\
\text { pe }\end{array}$ & \\
\hline
\end{tabular}

There are a number of works dealing which this theme which define and assess alternative ways of solving the problem of financing gap. From statistical point of view annual reports by the Organization for Economic Cooperation and Development (OECD) are the most informative ones. In terms of providing data on calculation methodology, determining financing gap and analysis of alternative financing the paper The European Capital Markets Study: Estimating the Financing Gaps of SMEs [15] and Estimating the SME Financing Gap in Europe and Can Marketplace Lending Help Bridge the SME Financing Gap? by A. McCahery [18] are the most comprehensive ones.

Then SMB representatives define the following main problems: search for buyers; difficulties with access to highly-qualified personnel; problems with search for target markets; legislation imperfection - governmental policy; corruption. All these factors influence the extent to which operating expenses and risks impede SMB's access to external financing.

\footnotetext{
${ }^{4}$ Distribution by regions is made in the paper in accordance with the classification of the United Nations Statistics Division. Source: Forbes Best Countries for Business. URL: https://www.forbes.com/best-countries-for-business/list/\#tab:overall (reference date: 23.01.2019).
} 
Summing up the information obtained from the above sources the authors analyze an alternative financing for each individual country. The most frequently mentioned alternative financing methods are business angels, venture funds, various government programs and other ways of government support [19].

\section{Country-Specific Determinants as Factors of Influence on SMB Performance Efficiency}

Since 1990s a number of studies has been conducted in order to define the factors which explain SME's performance efficiency. Nevertheless, in spite of a wide range of factors mentioned in literature the scientists failed to agree on a common point of view on this topic [20;21]. In the literature review on common characteristics of successful small enterprises and their founders [21] the authors came to the conclusion that "there is no such thing as a simple model". Besides, if we return to the list of SMB problems, we can see that it is comprised of external environment factors.

One of the latest and most comprehensive systematizations of external environment factors which define SME development is presented in the paper by D.R.Khairullina [22]. The author divided the factors into two groups depending on the extent of influence on business (direct and indirect one). The direct influence factors are: suppliers, customers, institutional-organizational environment, government support system, competitors, contact audience, support infrastructure. The indirect influence factors are as follows: social and demographic, legal, political, social and cultural, research and development, natural and climatic, international ones.

Under current conditions of economic management, it is reasonable to consider external and internal factors as a whole in order to develop effective management solutions. Speaking of characteristics of business, its internal factors scientists place emphasis on human capital [23; 24], financial standing [25], size and organizational structure of a company [26] and corporate culture [27].

As for characteristics of the entrepreneur himself the studied literature suggests that business success is related to certain psychological and personal qualities, first of all, readiness to risk in complex situations [28; 29], flexibility and ability to align oneself with conditions of uncertainty [30], masculinity and leadership skills [31], ability to make decisions and smooth problems over, tendency towards creativity and innovativeness [28], education, knowledge and experience [20]. The abovementioned research use polls as an information base. If we consider personal qualities of entrepreneurs and their subordinates we can use Hofstede's paper, his six dimensions of personality in accordance with country-specific determinants (power distance (degree of participation in taking decisions), individualism / collectivism, masculinity / femininity, uncertainty acceptance, orientation time horizon (long-term / short-term)). However, some papers disagree with Hofstede's dimensions results [33].
In spite of the studies which emphasize importance of personality determinants there are papers which results show that entrepreneur's personality characteristics are formed and changed depending on experience, improving management skills and business environment [4; 5]. Researches by M. Simpson, J. Padmore, N. Newman and M. Simpson, N. Tuck, S. Bellamy confirm importance of knowledge and experience obtained in various trainings [20;7].

Influence of business climate determinants on success and failures of business is a matter of common knowledge. Such determinants comprise: social and political systems, legislation, infrastructure factors, the technological development level and trends in this sphere, competitive intensity $[21 ; 34 ; 35]$. The paper by E. G. Rogoff [34] describes in detail how entrepreneurs and business owners perceive the factors which influence SMB performance. As a result 11 factors were revealed which include external ones (beyond the entrepreneur's control): business regulation system at the legislative and executive level, labour market, external financing system, competition, economic environment, technological development level. Applying another approach - the Automatic Network Replenishment (ANR) to detect priority success factors of Turkish SME Karpak and Topcu [36] made the conclusion that external factors (political environment, legislation, legal and regulatory framework for SMB, competitive intensity and maturity of the industry sector) have a greater influence as distinct from internal ones. Study of the factors which influence small and medium business in the British chemical industry showed that the most important factor is the legal framework [37]. Also on the basis of the BEEPS database G.V.Shirokova and K.A.Bogatyreva [38] showed that a negative assessment of tax regulation, judiciary system and political instability increases internationalization of SMB companies indicating obstacles to SMEs' development - a negative assessment of tax rates, corruption and procedures of getting business registration licenses (permits).

The external factors indicative of the level of democracy, public management and supremacy of law are described in the paper by G.L. Munck [39]. The author lists the indicators which represent legal and political factors of external environment dividing them into: rule of law indicators, democratic governance indicators, democratic regime indicators.

In accordance with the conclusions of the report of the Global Entrepreneurship Monitor there is a relation between business activity and economic growth of the country, however, it may differ depending on the country economic development, economics orientation: resources, efficiency and focus on innovation. The type of economics does not just determine the special features of SMB development but also forms a set of factors which influence foundation of new enterprises and business climate. A U-shape relationship was reveled between business activity and the level of economic development. It is explained by the fact that in a country where mac- 
roeconomic and political stability prevails strong enterprises develop. At the same time in the countries with a low GDP per capita small business dominates among the forms of entrepreneurship. In line with economic growth and revenue increase the growing demand is satisfied, employment grows, and significance of large companies increases simultaneously with slowdown in the rates of SMB development. Thus, decrease in business activity for the low-income countries may be considered a positive sign [40]. As for the relationship between macroeconomic indicators and SME Audretsch and Mahmood [41] asserted that the threat of business liquidation is greater when the level of unemployment in the industry sector is high. Gupta and Kartick [42] in their paper proved influence of economic and social factors on performance efficiency of the companies engaged in alternative energy forms.

As for research and development indirect factors of influence a research should be mentioned in accordance with which a hostile external environment forces SMB to improve the innovation strategy. Thus, the level of technological and product innovation grows having a positive effect on productive efficiency [43]. Audretsch [44] asserted that technological capability was very important over the long term for competitive ability of new companies. Agarwal and Audretsch [45] also presumed that corporate survivability depended on technology and the life cycle stage of the industry sector.

It is impossible to stay away from the corruption topic. It combines political, social and public-and-cultural implications. Vu, Tran, Nguyen, \& Lim [46] assert that corruption is a widespread phenomenon, especially in emerging countries. M.S. Safavian and D.H. Graham [47] conducted a research of SMB in Russia and summed up the following: small enterprises are exposed to the same level of bureaucracy as large ones. They indicate bureaucracy and rental payments as great obstacles in the way of business growth.

Tonoyan, Strohmeyer, Habib and Perlitz [48] showed that SMB's participation in corruptive transactions is partly related to the formal and informal institutional structure of each country and to a greater extent is due to low efficiency of financial and legal institutions. Considering illegal business practices as a widespread business practice entrepreneur get a substantiation in order to find excuses for their own corrupt practices. Moreover, the business environment where family relations, friends and bureaucracy prevail reduces contractor's opportunism to a corrupt transaction, thus paving the way for corruption. However, in the paper by A.Gladysheva, J.Kishilova [49] hypotheses of a positive influence of political relations (membership of an affiliated person / government agent in the board of directors) on access to debt financing and on a negative relationship between political relations and cost of debt have not been confirmed.

J. Hunady [50] basing analysis of corruption in European countries on polls, used indexes (Rule of Law, GE) in his paper to show the government and legal component. As a result, he revealed a negative relationship between the rule of law, government efficiency, public responsibility and corruption level in a country.

However, there are results which, at first view, defy common sense. Thus, in India a positive influence of bribery on export business and corporate innovation was noticed [51].

Analysis of literature on government support showed no unambiguous influence on performance of small and medium business. Angulo-Ruiz [52] determined that benefit from government support depends to a great extent on the market conditions and business environment.

Borbas [53] in his paper tells of the progress of influence of the Small Business Act (SBA) in Central and Eastern Europe which provides for a comprehensive cornerstone of policy in relation to SMB and development of entrepreneurship (estimation of efficiency of 10 programs in accordance with this Act). Actually, a lot of support measures may be offered by to those in power but far from all SMB representatives may use them. The author thinks that Central and Eastern Europe is an "underperforming" region (the same result is stated in the paper by Berko, Agota [54] using Hungary as an example). Although, speaking of Austria, it should be noted that the country economics functioned well in the time of the crisis showing a low unemployment level which did not incite entrepreneurs to risk in case of numerous attractive but unsafe opportunities. In order to stimulate entrepreneurship growth the government made concessions to high-technology startups, and as the year-end results of 2018 show it had an effect. The author considers Poland the most successful country in the sample which cancelled the largest part of red-tapery and simplified the business registration procedure. SBA information on $\mathrm{SMB}$ in the Czech Republic is ambiguous because the entrepreneurship and self-employed persons' level is above the average over Europe, however, perception of business climate by SME representatives is rather negative. SBA also evaluates positively business climate in Romania. $20 \%$ of economically active population in this country are self-employed persons, $27 \%$ intend to go into business but it is emphasized that in Romania there are less opportunities for implementation of business ideas than in European countries on average. Hungary improved twice the entrepreneurship indicators in the period of 2009 to 2014. In the authors' opinion, a new taxation system, support of junior enterprises and providing various indirect government support (for example, assistance in drafting a business plan) facilitated it. The purpose of this paper is to show the main differences between postsocialist and non-socialist European countries. The paper makes the conclusion that the reason for underdevelopment of SMB in Western Europe in comparison to Central Europe is absence of significant support measures and dawdling of the procedures going on in political institutions. In the opinion of L. Borbas [53], the gap between the west and east of Europe will grow if the above problems are dismissed. 
However, when we speak of Great Britain's experience, one should mention the paper by Galbraith, McAdam, Woods, McGowan [55] on the necessity to elaborate one of SME support programs concerning taking into consideration the political and innovation component of the business environment.

Bergström [56] pointed out in his paper that subsidy allocation is not always effective because it is based on pollical relations and is performed for political purposes instead of prospects and social influence of the company. Consequently, the companies will, probably, "incur unofficial expenses" in order to win the government support. These phenomena in the sphere of government support may increase deviations in efficient resource allocation among companies and, consequently, may result in a slow growth of income or even decrease of return on assets [57]. Nguyen, Tran, Do also emphasize in their paper absence of a positive relation between the government support and SME profitability as well as a necessity to focus government programs on startup support rather than on noneffective private companies in Vietnam (the researchers use the PCI index in their paper).

There is no common conclusion concerning influence of government support on efficiency of SMB activity. We have examples of positive influence of government support [58] as well as those of negative influence. So, the paper by Bergström [56] shows that government support reduces return on sales.

Study of public and cultural diversity also does not produce a conclusive result. When Majocchi, Valle and D’angelo [59] studied Italian companies for a five-year period they established that multinationality as such had no influence on corporate performance. Gupta and Kartick [42], in their turn, pointed out the importance of national and cultural aspects which explain the difference in corporate financial indicators involved in alternative energy forms in various countries.

Literature offers different interpretations of the corporate performance efficiency: from growth of sales and sales indicator logarithm per an employee $[60 ; 61]$ to return on assets (the indicator most frequently used in financial literature).

As for influence of corporate internal characteristics on performance efficiency, Whittington [62] asserted that larger companies, as a rule, had different opportunities and abilities for attaining higher figures in comparison to small business due to the scale effect. Some researches also prove a significant influence of the company size on its performance [63-65].

According to the trade-off theory higher-income companies should use more debt to gain on the tax of interest deduction [66] which implies a positive relation between profitability and debt because large companies are more attractive than small enterprises for a fund receiver when he needs external financing. On the contrary, the pecking order theory assumes that if financing is necessary the company investments have a certain hierarchy when funding sources are chosen. First, the accumulated own funds are used, then, third-party resources, and then debts and, finally, issue of new shares. Profitable companies have an opportunity of self financing and a lower need in debt increment [67], so, the pecking order theory presumes a negative relation between the debt and profitability. A negative relation between corporate profitability and debt was also detected in empirical research [68-70]. While on the subject of external influence factors, I. Zdráhal, G. Chmelíková, I. Blažková [71] assert that GDP growth and market competition have a positive impact on corporate profitability.

A. Sadeghi [72] proved that external factors ("success factors"), especially the policy and regulation, technology factor and entrepreneurship determinants are the most important ones in achieving success by small and medium high-tech enterprises.

Political risk is a part of the overall risk of corporate operation. Kobrin [73] defines political risk as a probability of negative consequences caused by political events. More generally, political risk may be defined as any unexpected change in the country's governmental policy which influences the business environment in which companies operate [74]. In 2000 Henisz [75] calculated the political constraint index (PCI) which measured this type of risk and had already been used in numerous empiric papers [59]. In the countries where politicians are more prudent in their decisions the index is higher. The majority of research studied influence of political instability on the investment level in the country, the result was a negative relation between these two indicators. The negative relation is due to the fact that when a political risk is high negative consequences of political events are more probable. This phenomenon is pertinent for large companies because they have different means to influence on and negotiate with political authorities concerning their investments, consequently, they can manage this particular risk. The situation is quite reverse with small and medium enterprises which have a smaller market power when investing in a foreign country in case of business expansion, taking into consideration a limited amount of transferred funds. Moreover, a potential impact of an unfavourable decision of political authorities is greater for SME because unfavourable political events may place them under the threat of liquidation. This is to say that for small enterprises investments in high political risk countries may be reasonable only if return on investment justifies the extra risk. Zahra, Garvis [76] used the subjective measurement of perceived environment risk and found out that companies which strain after international expansion have a higher profitability. Consequently, the higher the political risk which SME face the greater the economic performance. It is confirmed by the paper of Majocchi, Valle, D'angelo [59].

Majocchi, Valle, D'angelo [59] showed that the following indicators were the most important ones in influence on performance: political risk, financial stability of a country and economic growth (the latter had been confirmed by 
T.J. Andersen [77] earlier). The general conclusion made by the authors states that for SME choice of the territory where subsidiary companies are founded is decisive because it influences greatly their overall economic performance.

R.W. Click [78] in his research revealed that business cycle and country rating have a positive impact on profitability of foreign direct investment. This effect should be stronger for SME because a decision on setting up a company entails contribution of numerous resources and, as a rule, is related to large markets. Consequently, if a market functions well and the economic state measured by the country rating is positive it is most probable that this positive effect will be manifested in corporate economic performance.

The paper which studied Russian SMB [79] showed a negative influence of corruption on corporate performance. Bureaucracy and significant transaction costs increase small enterprises' vulnerability to administrative pressure. In order to survive in such environment Russian SME should be of a larger size in comparison to SME of developed countries. A. Mitra [51] also made conclusions on bribe consequences and corporate performance in India. Bribes take on the role of corporate income tax and reduce performance.

Thapa [80] established the following key factors defining micro-enterprise performance: management skills, achievement need, independence need, creativity, internal locus of control and management foresight; the company-specific factors, in particular its age, size and starting financial restrictions; environment-related factors.

\section{Hypotheses Generation}

As a result of the conducted research the following hypotheses founded on theoretical and empiric bases have been put forward.

$H_{1}$ : there is a significant positive relation between the innovative development level and SMB performance.

The innovative development is important for companies from the point of view of external and internal influence. In particular it concerns SME. Considering the innovation development level as an internal factor one can mention the papers by Stewart Jr, Roth [28] and Simpson, Tuck, Bellamy [20] which discuss the importance of creativity, entrepreneurial innovation, entrepreneur's education, knowledge and experience as the factors influencing success in corporate performance. The innovation development level may also be considered as an external indirect influence factor which has been proved in the papers by Audretsch [44], Agarwal, Audretsch [45] and Perez-de-lema, Hansen, Madrid-Gujjarro, Silva-Santos [43]).

$\mathrm{H}_{2}$ : there is a significant positive relation between the country regulatory environment and SME performance.

Papers by Karpak, Topcu [36], Lampadarios [37] have proved significance of legislation and legal and regula- tory framework for SME operations. In particular we would like to emphasize the legal framework related to borrowers' and creditors' rights protection because the major obstacle in the way of SME global development is insufficiency of external financing. This has been proved in numerous publications and statistical materials.

$\mathrm{H}_{3}$ : there is a significant negative relation between the corruption level in a country and SME performance.

Analysis of academic papers dedicated to this topic found out cases of a positive relation between the corruption component in a country and corporate performance, however, these cases occur mainly in Asian countries ("the East Asian paradox") [51]. This paper considers SME of European countries, for this reason the hypothesis above has been proposed. A negative influence of corruption (in various forms) in this sense has been revealed in the papers by M.S. Safavian, D.H. Graham [47], G.V.Shirokova and T.V.Tsukanova [38], Golikova, Kuznetsov [79].

$\mathrm{H}_{4}$ : there is a significant positive relation between public and cultural determinants characteristic of successful entrepreneurs and SMB performance.

Such determinants comprise: risk propensity [28; 29], flexibility and ability to align oneself with conditions of uncertainty [30], masculinity and leadership skills [31], ability to make decisions and smooth problems over. It is supposed that in the countries where the determinants (according to Hofstede dimensions) are presented by small figures SMB performance is higher.

$\mathrm{H}_{5}$ : there is a significant positive relation between business climate (from the macroeconomic point of view) and SME performance.

In an environment where macroeconomic and political stability prevails strong enterprises develop. Earlier the positive relation between macroenvironment and performance has been detected by Audretsch, Mahmood [41] and Gupta, Kartick [42].

$H_{6}$ : there is a significant negative relation between the political risk level in a country and SME performance.

When the political risk is high the possibility of detrimental consequences of political events is greater. Thus, we make an assumption that for small enterprises investments in high political risk countries may be reasonable only if return on investment justifies the extra risk. So, the higher the political risk which SME face the greater the economic performance. It is confirmed by the paper of Zahra, Garvis [76], Majocchi, Valle, D’angelo [59].

$\mathrm{H}_{7}$ : there is a significant positive relation between $\mathrm{SMB}$ size and its profitability.

This assertion has been discussed above [63-65].

$H_{8}$ : there is a significant negative relation between financial leverage and SME's return on assets.

The empiric studies by Degryse [68], Mateev, Poutziouris, Ivanov [69], Nunes, Serrasqueiro [70] detected a negative relation between profitability and corporate indebtedness. 


\section{Data and Methodology}

The sample of small and medium enterprises used in this research has been made on the basis of the Amadeus database (Bureau Van Dijk). The geographical spread of the sample has been defined on the basis of the Forbes rating Best Countries for Business for 2018 which presents clusterization of certain European regions. The framework established by the European Commission and described above is taken into consideration as criteria for defining SMB. Thus, the sample comprises enterprises of 24 countries. The initial sample consisted of 250,000 companies. In general, the research applies 12 samples: the total sample, 4 samples in accordance with regional distribution of Europe by the United Nations Statistics Division, 2 samples covering developed and emerging countries (in accordance with IMF's distribution), 5 samples of innovative companies (total and the one related to regions of Europe) (Figures 3-5).

The Amadeus platform was used in order to obtain financial indicators describing company characteristics. For example, the key performance indicator in this paper is represented by return on assets presented as net profit - total assets.

Other indicators - corporate characteristics were also collected. It reduced the initial sample significantly because a lot of companies have no necessary data. So, the SME sample was diminished up to 54,512 companies. A fiveyear period of 2013 to 2017 was chosen for the research. The analysis uses the panel data methodology, so the sample accounts for 272,560 unique observations.

Figure 3. Percentage ratio of companies in the total sample

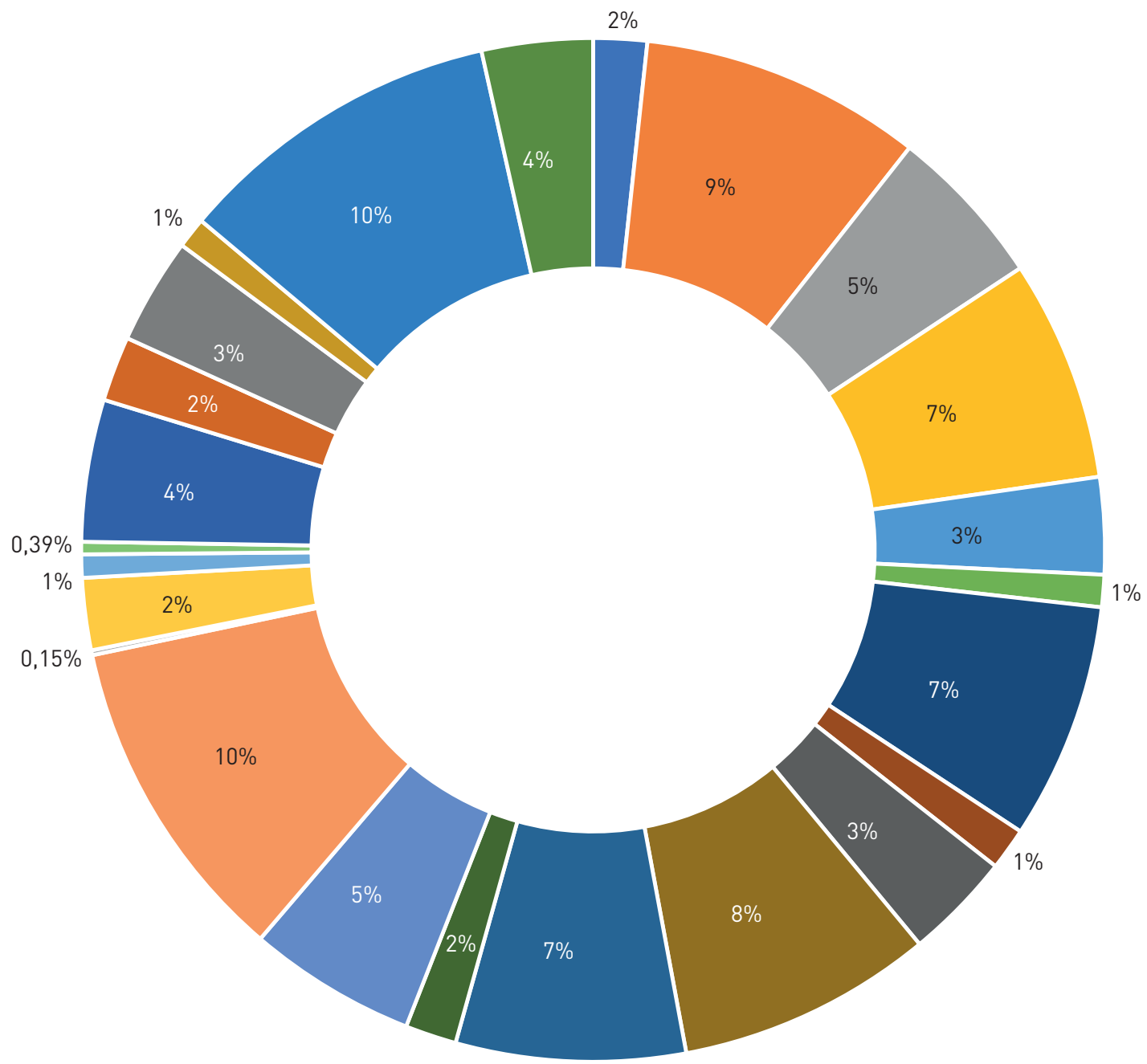

\begin{tabular}{|c|c|c|c|}
\hline Austria & mungary & - Portugal & - Spain \\
\hline Belgium & Italy & nomania & Estonia \\
\hline Bulgaria & - Luxembourg & n Russia & - Finland \\
\hline Czech Republic & - Latvia & —Slovenia & - France \\
\hline Germany & the Netherlands & - Sweden & - Great Britain \\
\hline E Denmark & Poland & - Ukrain & - Greece \\
\hline
\end{tabular}


Figure 4. Number of small and medium enterprises in Western Europe (1), Eastern Europe (2), Northern Europe (3), Southern Europe (4)

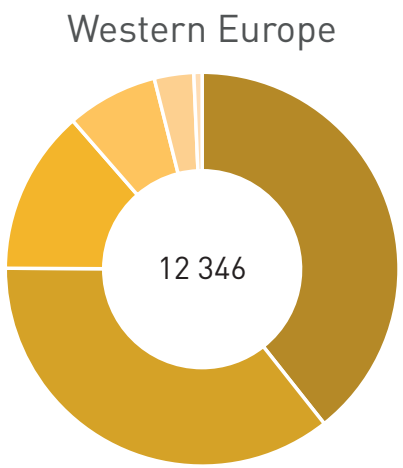

Belgium

- France

- Germany

- Austria

the Netherlands

Luxembourg
Eastern Europe

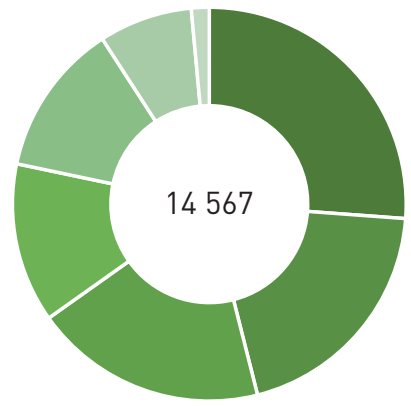

Czech Republic

- Hungary

- Bulgaria

- Ukrain

- Russia

- Romania

- Poland

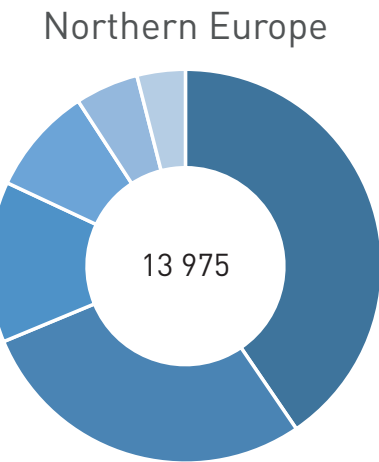

- Sweden

- Great Britain

- Finland

- Latvia

Estonia

- Denmark
Southern Europe

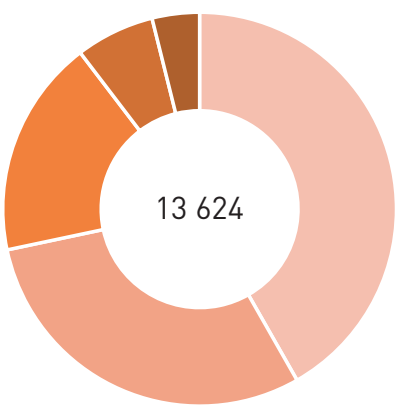

Italy

- Spain

- Portugal

- Greece

- Slovenia

Source: author's calculations.

Figure 5. Number of: small and medium enterprises of developed and emerging European countries (1), innovative European SME (2)

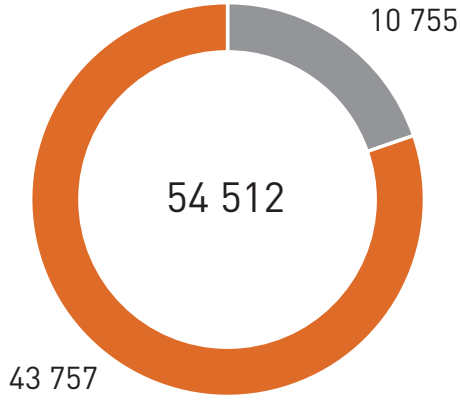

- Emerging countries

- Developed countries

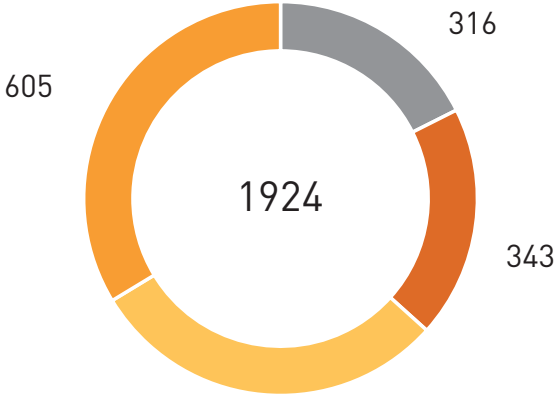

533

- Eastern Europe - Southern Europe

- Northern Europe $\quad$ Western Europe

Source: author's calculateions.

Apart from the indicators on each certain company we have collected country-specific determinants applying the methodology developed by D.R.Khairullina [22]. The factor system she offered is presented in Figure 6. On the basis of this system indexes characterizing the external environment factors have been collected.

The macroeconomic indicators for each country stated in the paper are mainly taken from the publicly available database Worldbank.

The sample of innovation small and medium enterprises is worth noting individually. SME's definition as innovation enterprises was based on the idea from the paper by Dagmar Vávrová [81] which uses industrial NACE codes of the Bureau Van Dijk database. The paper determines the following range of innovative sectors: drug production
(NACE code: 21.); electronics, optics, equipment manufacturing (NACE codes: 26.1 - 26.8); audio-visual devices (NACE codes: 59, 60); ICT sector (NACE codes: 61, 62); information sector (NACE codes: 63); research and development (NACE codes: 72.1, 72.2).

\section{The main variables}

The purpose of this research is to evaluate influence of external factors on SMB performance represented as return on assets (ROA). In this relation we can define two groups of variables (Figure 7): company-specific determinants and country-specific determinants. The first group is comprised of: the natural logarithm of the number of employees LnEMP as the company size and the balance 
variable - a debt to own DTA ratio - financial leverage. The second group consists of the variables - indexes which show different types of external influence on SME performance.

- legal and political factors of external environment the rule of law indicators (The Heritage Foundation \& Wall Street Journal's Index of Economic Freedom WSJI, the corruption perception index CPI, rule of law index ROL, civil liberties index CLI, legal rights index LRI);

- legal and political factors of external environment democratic governance indicators (country-specific rating of political stability PSI), the governance efficiency index GEI, political constraint index PCI);

- legal and political factors of external environment democratic regime indexes (the political rights index PRI);

- economic and sociodemographic indexes (business climate index represented as the index of expenses on business startup in a country CBS);

- research and development index - the global innovation index GII;

- $\quad$ public and cultural environment index - cultural diversity CDI.

Figure 6. System of the factors defining small business development

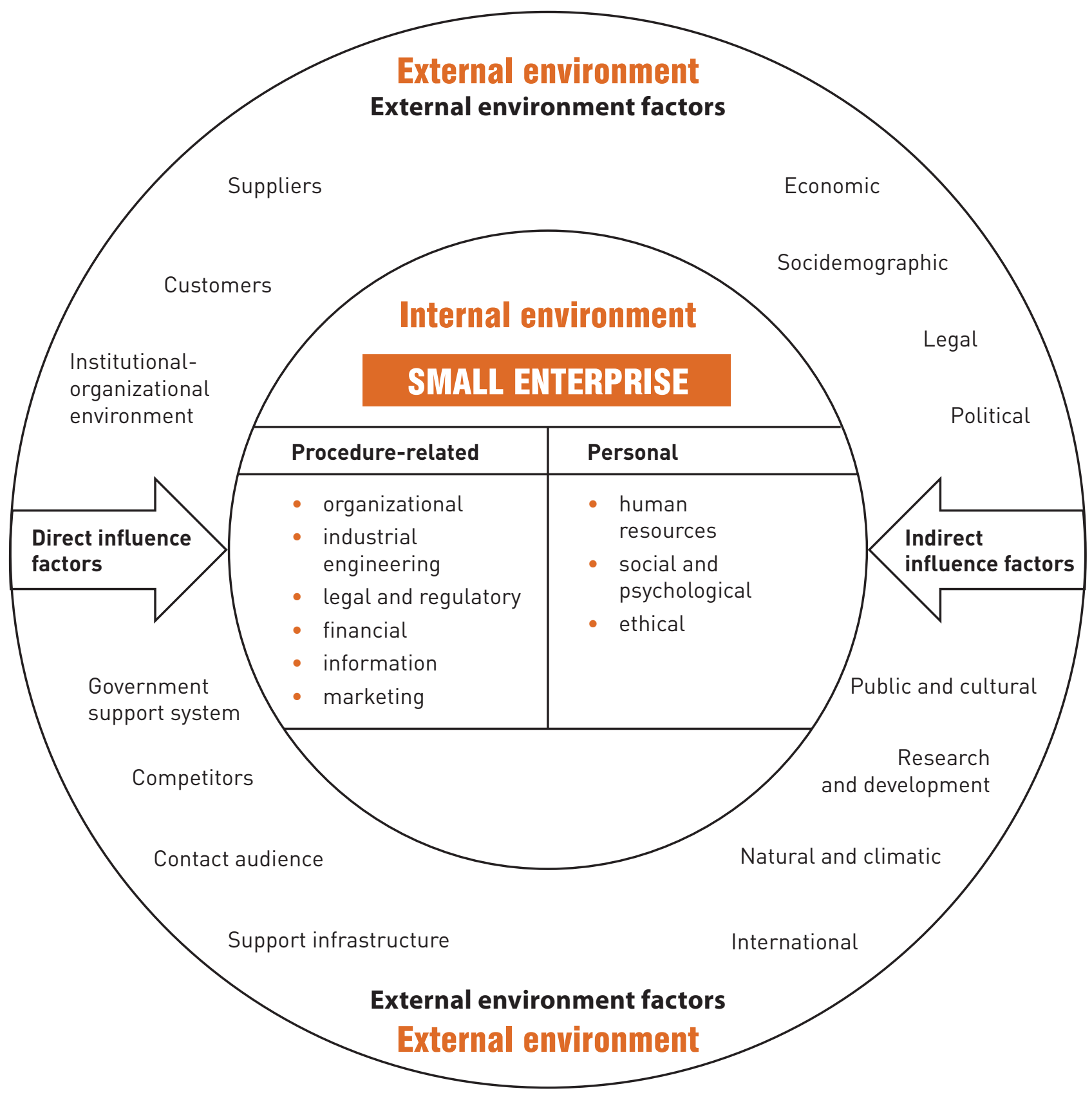

Source: [22].

Scoring is used in the rating systems to create indexes. 
Figure 7. Graphic representation of the model

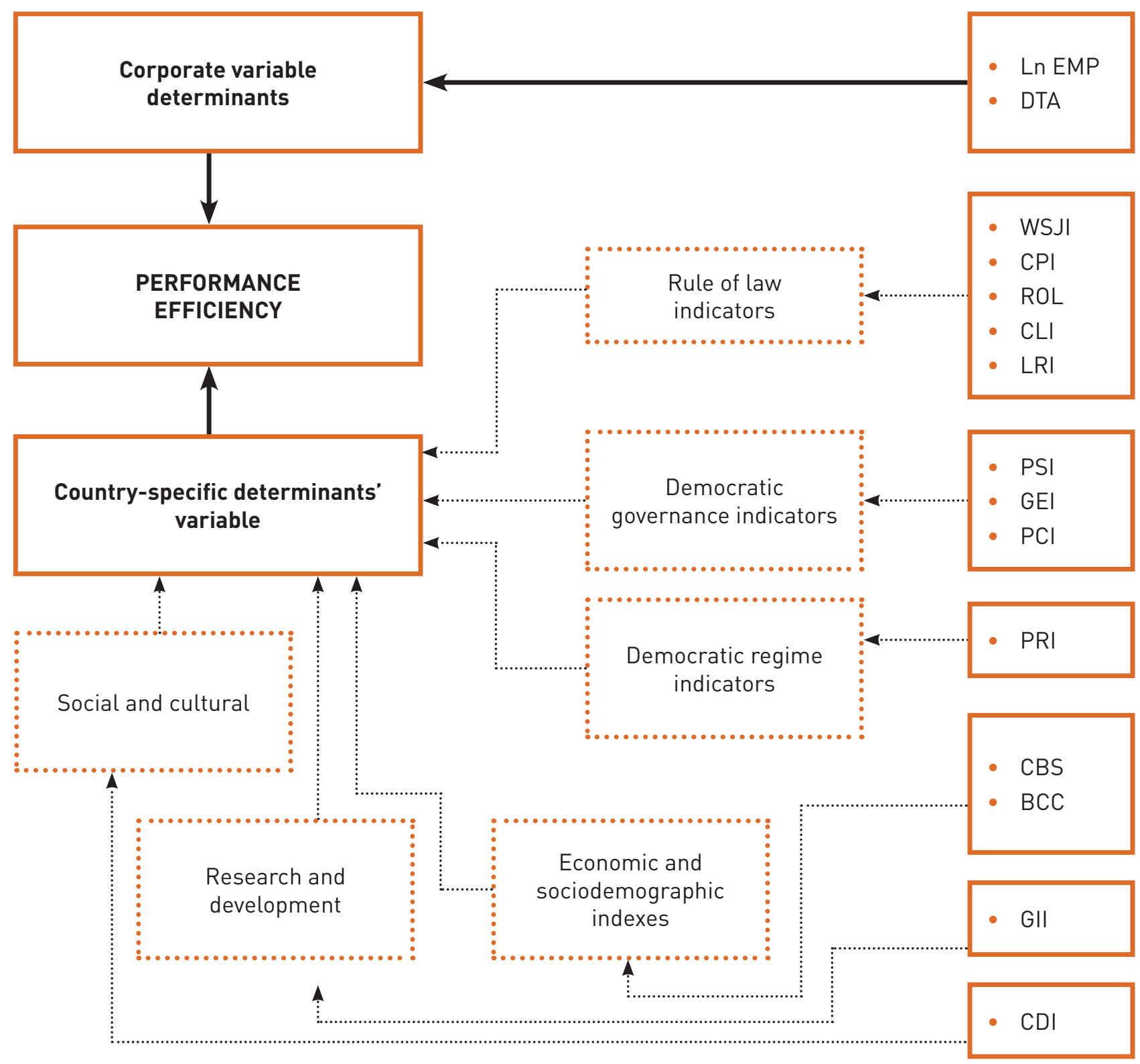

Source: the diagram was developed by the author of the paper.

The variables are described in Table 3 in more detail.

Table 3. Expected variables values, units of measure and sources

\begin{tabular}{|c|c|c|c|c|}
\hline Variable & Definition & $\begin{array}{l}\text { Expected } \\
\text { sign }\end{array}$ & Source & Measurement \\
\hline \multicolumn{5}{|c|}{ Rule of law indexes } \\
\hline WSJI & Economic freedom index & + & https://www.heritage.org & Index from 0 to 100 \\
\hline CPI & $\begin{array}{l}\text { Corruption perception } \\
\text { index }\end{array}$ & + & https://www.transparency.org & Index from 0 to 100 \\
\hline $\mathrm{ROL}$ & Rule of law index & + & https://worldjusticeproject.org & Index from 0 to 1 \\
\hline CLI & Civic liberties index & + & https://freedomhouse.org & Index from 0 to 100 \\
\hline LRI & Legal rights index & + & www.worldbank.org & Index from 0 to 10 \\
\hline
\end{tabular}




\begin{tabular}{|c|c|c|c|c|}
\hline Variable & Definition & $\begin{array}{l}\text { Expected } \\
\text { sign }\end{array}$ & Source & Measurement \\
\hline \multicolumn{5}{|c|}{ Democratic governance index } \\
\hline PSI & Political stability index & + & https://www.theglobaleconomy.com & Index from $0-3$ to 3 \\
\hline PCI & Political constraint index & - & https://mgmt.wharton.upenn.edu & Index from 0 to 1 \\
\hline GEI & $\begin{array}{l}\text { Governance efficiency } \\
\text { index }\end{array}$ & + & www.worldbank.org & Index from 0 to 10 \\
\hline
\end{tabular}

Economic and sociodemographic indicators

\begin{tabular}{|c|c|c|c|c|}
\hline CBS & Business climate & $=$ & www.worldbank.org & Index from 0 to 200 \\
\hline BCC & Business climate (macro) & + & $\begin{array}{l}\text { www.worldbank.org www. } \\
\text { standardandpoors.com }\end{array}$ & Dummy variable \\
\hline
\end{tabular}

Research and development indicator

GII Global innovation index $+\quad \begin{aligned} & \text { https:/www.globalinno } \\ & \text { vationindex.org }\end{aligned}$

Public and cultural indicator

CDI Cultural diversity index $+\quad \quad$ https://www.hofstede-insights.com $\begin{aligned} & \text { Sum of } 4 \text { measure- } \\ & \text { ments from } 0 \text { to } \\ & 100\end{aligned}$

Company-specific variables

\begin{tabular}{|c|c|c|c|c|}
\hline LnEMP & Number of employees & + & Amadeus Database & $\begin{array}{l}\text { Natural logarithm } \\
\text { of the number of } \\
\text { employees }\end{array}$ \\
\hline DTA & Financial leverage & - & Amadeus Database & $\begin{array}{l}\text { Total debt / } \\
\text { Total assets }\end{array}$ \\
\hline
\end{tabular}

Source: offered by the author.

It is reasonable to explain CPI, CDI and CBS indexes.

The corruption perception index, according to the hypothesis suggested before is negatively associated with corporate performance but as long as the value of this index grows along with corruption decrease we expect to see in the results a positive relation of this indicator with ROA.

The cultural diversity index is interpreted differently in various sources and is used in various scientific fields (internal technology, mass media, psychology, finance etc.). This index is based on the results of polls of persons - representatives of 93 countries consolidated into four (six, since recently) dimensions which comprise Hofstede' cultural dimensions typology. In this research in accordance with the studied literature four dimensions have been chosen which correspond to successful entrepreneurship: uncertainty avoidance (UAI as opposed to risk propensity), masculinity (MAS), internal locus of control, long-term orientation (LTO).

The values of the above indicators are added together for each country separately (except for UAI, as long as it is a reverse indicator to the one we need we deducted the UAI value from the maximum possible value -100).

CBS index which represents costs for business startup in a country, like CPI in the hypothesis above has the negative sign, however, the higher the value the more favourable the conditions for business startup are (see the expenses below).

The dummy variable BCC which represents business climate in a country from the macroeconomical point of view belongs to the economic and sociodemographic group of variables. The variable takes on the value one when the condition is observed at which the rate of inflation in the country is below the average for the countries in the sample while the credit rating of the country and GDP growth are above the average across the sample. Thus, the variable is created to represent favourability of macroeconomic conditions for business. The country credit rating was taken from the Standard \& Poor's database. In order to transform it into a linear scale the rating value $\mathrm{D}$ was imputed as one and subsequently in the same way, in ascending order, all letter designations of the rating were transformed. 


\section{Research Methodology and Theoretical Model}

This research implies econometric regression analysis of panel data. There are several stages of the analysis: defining the model types (pooled, random-effects or fixed-effects one); elimination of econometric supposition disarrangement (problems of heteroscedasticity, endogeneity, multicollinearity).

In order to choose the best specification three tests have been carried out. When choosing from among the pooled regression model and fixed-effects model the Wald test yielded the results in favour of the latter model. We also conducted the Breusch-Pagan test which showed that in all research models the zero hypothesis was rejected substantiating the choice of the random-effects model. As a result of the Haussmann test the zero hypothesis was discarded in all cases which means that the fixed-effects model specification is necessary. See all test results related to choosing specification in table 4 .

Table 4. Samples testing results for defining the model type

\begin{tabular}{|c|c|c|c|c|c|c|}
\hline \multirow{2}{*}{\multicolumn{2}{|c|}{$\begin{array}{l}\text { Dependent variable model } \\
\text { specification }\end{array}$}} & Total & Northern & Western & Southern & Eastern \\
\hline & & sample & Europe & Europe & Europe & Europe \\
\hline \multirow{2}{*}{ Breusch-Pagan test } & $x^{2}$ & $4.2 \mathrm{e}+05$ & $1.2 \mathrm{e}+05$ & $1.0 \mathrm{e}+05$ & $1.1 \mathrm{e}+05$ & $1.0 \mathrm{e}+05$ \\
\hline & P-value & 0.0000 & 0.0000 & 0.0000 & 0.0000 & 0.0000 \\
\hline \multirow{2}{*}{ Wald test } & $\mathrm{F}$ & 45.40 & 68.54 & 48.45 & 38.55 & 35.49 \\
\hline & P-value & 0.0000 & 0.0000 & 0.0000 & 0.0000 & 0.0000 \\
\hline \multirow{2}{*}{ Haussmann test } & $x^{2}$ & $11,178.08$ & 131.25 & 62.20 & 480.46 & $3,955.09$ \\
\hline & P-value & 0.0000 & 0.0000 & 0.0000 & 0.0000 & 0.0000 \\
\hline
\end{tabular}

Taking into consideration the test results (using the total and particular samples by European regions) and presence of the time-constant variables important for this research in particular, we took the decision to apply both fixed- and random-effects models.

The main model proposed for research initially appeared as follows:

$$
\begin{aligned}
& \text { Perform }_{\mathrm{it}}=\alpha+\beta_{1} \mathrm{LnEMP}_{\mathrm{it}}+\beta_{2} \mathrm{DTA}_{\mathrm{it}}+\beta_{3} \mathrm{CPI}_{\mathrm{it}}+ \\
& +\beta_{4} \mathrm{GII}_{\mathrm{it}}+\beta_{5} \mathrm{WSJI}_{\mathrm{it}}+\beta_{6} \mathrm{ROL}_{\mathrm{it}}+\beta_{7} \mathrm{CLI}_{\mathrm{it}}+\beta_{8} \mathrm{LRI}_{\mathrm{it}}+ \\
& +\beta_{9} \mathrm{PSI}_{\mathrm{it}}+\beta_{10} \mathrm{GEI}_{\mathrm{it}}+\beta_{11} \mathrm{PCI}_{\mathrm{it}}+\beta_{12} \mathrm{PRI}_{\mathrm{it}}+\beta_{13} \mathrm{CDI}_{\mathrm{it}}+ \\
& +\beta_{14} \mathrm{CBS}_{\mathrm{it}}+\beta_{15} \mathrm{BCC}_{\mathrm{it}}+\varepsilon_{\mathrm{it}}
\end{aligned}
$$

where Perform $_{\text {it }}$ - return on assets for each company $\mathrm{i}$ within the period of t; $\alpha$ - constant; $\varepsilon_{\text {it }}-$ standard error for company i within the period of $\mathrm{t}$.

On the basis of tests, in order to reveale the problems of multicollinearity, endogeneity, heteroscedasticity, which influence consistency and efficiency of estimates the models were rearranged.

The test for multicollinearity using the Pearson correlation matrix and the variance inflation factor (VIF) revealed a serious multicollinearity problem and, thus, helped to choose between variables - indexes $\mathrm{k}$ from the same group of external factors which makes the indexes (in the context of this paper) interchangeable. We selected variables from each individual sample in the following groups: rule of law indicators; democratic governance indicators; economic and sociodemographic indexes.

In order to eliminate the endogeneity problem between financial leverage and return on assets the DTA indicator in the research is lagged within the period of $\mathrm{t}-1$. So, the principal model is simplified as follows:

$$
\begin{aligned}
& \text { Perform }_{\mathrm{it}}=\alpha+\beta_{1} \mathrm{LnEMP}_{\mathrm{it}}+\beta_{2} \mathrm{DTA}_{\mathrm{i}(\mathrm{t}-1)}+\beta_{3} \mathrm{CPI}_{\mathrm{it}}+ \\
& +\beta_{4} \mathrm{GII}_{\mathrm{it}}+\beta_{5} \mathrm{LRI}_{\mathrm{it}}+\beta_{6} \mathrm{ROL}_{\mathrm{it}}+\beta_{7} \mathrm{PSI}_{\mathrm{it}}+\beta_{8} \mathrm{PCI}_{\mathrm{it}}+ \\
& +\beta_{9} \mathrm{CDI}_{\mathrm{it}}+\beta_{10} \mathrm{CBS}_{\mathrm{it}}+\beta_{11} \mathrm{BCC}_{\mathrm{it}}+\varepsilon_{\mathrm{it}} .
\end{aligned}
$$

Some models of samples according to European regions are modified due to multicollinearity. So, in the models for Southern and Western Europe the GII indicator will be assessed separately, while in Northern and Eastern Europe the CPI indicator will be evaluated this way. Separate regressions were made for the rest of the variables not included in the models.

The autocorrelation and heteroscedasticity problems result in inefficiency of coefficients assessments while they are still unbiased and consistent.

In order to detect inhomogenuity of observations (heteroscedasticity) we conducted a modified Wald test. The tests results included in Table 5 are indicative of heteroscedasticity in all existing models. The determined problem is corrected by means of White corrections due to which $t$ statistics increase and standard deviations reduce.

The period of research is five years which may be considered a short temporal series. For this reason the autocorrelation problem will have no serious consequences.

We also complied two samples which subdivide the total sample into developed and emerging countries. The models in these samples are tested for choice of specification (see the results in Table 6). 
Table 5. Test results for heteroscedasticity

\begin{tabular}{|c|c|c|c|c|c|c|}
\hline & & $\begin{array}{l}\text { Total } \\
\text { sample }\end{array}$ & $\begin{array}{l}\text { Northern } \\
\text { Europe }\end{array}$ & $\begin{array}{l}\text { Western } \\
\text { Europe }\end{array}$ & $\begin{array}{l}\text { Southern } \\
\text { Europe }\end{array}$ & $\begin{array}{l}\text { Eastern } \\
\text { Europe }\end{array}$ \\
\hline \multirow{2}{*}{ Wald test } & $x^{2}$ & $8.1 e+10$ & $2.4 \mathrm{e}+08$ & $7.1 e+09$ & $5.0 \mathrm{e}+08$ & $7.3 e+08$ \\
\hline & P-value & 0.0000 & 0.0000 & 0.0000 & 0.0000 & 0.0000 \\
\hline
\end{tabular}

Table 6. Results of samples testing in order to define the model type

\begin{tabular}{|c|c|c|c|}
\hline \multicolumn{2}{|c|}{ Dependent variable model specification } & Developed countries & Emerging countries \\
\hline \multirow{2}{*}{ Breusch-Pagan test } & $x^{2}$ & $1.1 \mathrm{e}+05$ & 24775.87 \\
\hline & P-value & 0.0000 & 0.0000 \\
\hline \multirow{2}{*}{ Wald test } & $\mathrm{F}$ & 6.32 & 5.73 \\
\hline & P-value & 0.0000 & 0.0000 \\
\hline \multirow{2}{*}{ Haussmann test } & $\chi^{2}$ & $1,783.69$ & 415.77 \\
\hline & P-value & 0.0000 & 0.0000 \\
\hline
\end{tabular}

Table 7. Test results for heteroscedasticity

$\begin{array}{lccc} & & \text { Developed countries } & \text { Emerging countries } \\ \text { Wald test } & \chi 2 & 1.2 \mathrm{e}+10 & 5.5 \mathrm{e}+08 \\ & \text { P-value } & 0.0000 & 0.0000\end{array}$

Now we proceed to developing a market for innovation companies' sample. In order to define the model specification tests were carried out (Table 8).

Table 8. Samples testing results for defining the model type

\begin{tabular}{|c|c|c|c|c|c|c|}
\hline \multicolumn{2}{|c|}{$\begin{array}{l}\text { Dependent variable model } \\
\text { specification }\end{array}$} & $\begin{array}{l}\text { Total } \\
\text { sample }\end{array}$ & $\begin{array}{l}\text { Northern } \\
\text { Europe }\end{array}$ & $\begin{array}{l}\text { Western } \\
\text { Europe }\end{array}$ & $\begin{array}{l}\text { Southern } \\
\text { Europe }\end{array}$ & $\begin{array}{l}\text { Eastern } \\
\text { Europe }\end{array}$ \\
\hline \multirow{2}{*}{ Breusch-Pagan test } & $x^{2}$ & $5,612.19$ & $1,573.21$ & $1,998.54$ & $1,115.28$ & 956.93 \\
\hline & $\mathrm{P}$-value & 0.0000 & 0.0000 & 0.0000 & 0.0000 & 0.0000 \\
\hline \multirow{2}{*}{ Wald test } & $\mathrm{F}$ & 7.53 & 7.08 & 7.88 & 7.84 & 7.13 \\
\hline & P-value & 0.0000 & 0.0000 & 0.0000 & 0,0000 & 0.0000 \\
\hline \multirow{2}{*}{ Haussmann test } & $x^{2}$ & 62.67 & 12,70 & 13,15 & 12.94 & 2.29 \\
\hline & P-value & 0.0000 & 0.2409 & 0.2152 & 0.2269 & 0.9972 \\
\hline
\end{tabular}

Taking into consideration the obtained results and the necessity to accept for consideration the time-constant variables we took the decision to use fixed- and random-effects models.

Taking into consideration the multicollinearity problem the following theoretical models were made:

for developed countries

Perform $_{\text {it }}=\alpha+\beta_{1} \mathrm{LnEMP}_{\mathrm{it}}+\beta_{2} \mathrm{DTA}_{\mathrm{i}(\mathrm{t}-1)}+\beta_{3} \mathrm{CPI}_{\mathrm{it}}+$ $+\beta_{4} \mathrm{GII}_{\mathrm{it}}+\beta_{5} \mathrm{LRI}_{\mathrm{it}}+\beta_{6} \mathrm{ROL}_{\mathrm{it}}+\beta_{7} \mathrm{PSI}_{\mathrm{it}}+\beta_{8} \mathrm{PCI}_{\mathrm{it}}+$ $+\beta_{9} \mathrm{CDI}_{\mathrm{it}}+\beta_{10} \mathrm{GEI}_{\mathrm{it}}+\beta_{11} \mathrm{CBS}_{\mathrm{it}}+\beta_{11} \mathrm{BCC}_{\mathrm{it}}+\varepsilon_{\mathrm{it}}$;

for emerging countries

$$
\begin{aligned}
& \text { Perform }_{\mathrm{it}}=\alpha+\beta_{1} \mathrm{LnEMP}_{\mathrm{it}}+\beta_{2} \mathrm{DTA}_{\mathrm{i}(\mathrm{t}-1)}+ \\
& +\beta_{3} \mathrm{CPI}_{\mathrm{it}}+\beta_{4} \mathrm{GII}_{\mathrm{it}}+\beta_{5} \mathrm{LRI}_{\mathrm{it}}+\beta_{6} \mathrm{CLI}_{\mathrm{it}}+\beta_{7} \mathrm{PSI}_{\mathrm{it}}+ \\
& +\beta_{8} \mathrm{PCI}_{\mathrm{it}}+\beta_{9} \mathrm{CDI}_{\mathrm{it}}+\beta_{10} \mathrm{GEI}_{\mathrm{it}}+\beta_{11} \mathrm{PRI}_{\mathrm{it}}+ \\
& +\beta_{10} \mathrm{CBS}_{\mathrm{it}}+\beta_{11} \mathrm{BCC}_{\mathrm{it}}+\varepsilon_{\mathrm{it}}
\end{aligned} .
$$

The heteroscedasticity test confirmed existence of this problem (see the results of the modified Wald test in Table 7). For this reason the Wald corrections were applied to the models.

Thus, we chose fixed- and random-effects models for the total sample and random-effects models for the samples according to European regions. 
Here we verify them for multicollinearity. The model appears as follows:

$$
\begin{aligned}
& \text { Perform }_{\mathrm{it}}=\alpha+\beta_{1} \mathrm{LnEMP}_{\mathrm{it}}+\beta_{2} \mathrm{DTA}_{\mathrm{i}(\mathrm{t}-1)}+ \\
& +\beta_{3} \mathrm{CPI}_{\mathrm{it}}+\beta_{4} \mathrm{GII}_{\mathrm{it}}+\beta_{5} \mathrm{LRI}_{\mathrm{it}}+\beta_{6} \mathrm{ROL}_{\mathrm{it}}+ \\
& +\beta_{7} \mathrm{PSI}_{\mathrm{it}}+\beta_{8} \mathrm{PCI}_{\mathrm{it}}+\beta_{9} \mathrm{CDI}_{\mathrm{it}}+\beta_{10} \mathrm{CBS}_{\mathrm{it}}+ \\
& +\beta_{11} \mathrm{BCC}_{\mathrm{it}}+\beta_{12} \mathrm{GEI}_{\mathrm{it}}+\varepsilon_{\mathrm{it}} .
\end{aligned}
$$

For certain European regions the principal model was rearranged taking into consideration multicollinearity. Separate regressions were made with the variables not included in the models.

The heteroscedasticity analysis showed existence of

\begin{tabular}{|c|c|c|c|c|c|c|}
\hline & & $\begin{array}{l}\text { Total } \\
\text { sample }\end{array}$ & $\begin{array}{l}\text { Northern } \\
\text { Europe }\end{array}$ & $\begin{array}{l}\text { Western } \\
\text { Europe }\end{array}$ & $\begin{array}{l}\text { Southern } \\
\text { Europe }\end{array}$ & $\begin{array}{l}\text { Eastern } \\
\text { Europe }\end{array}$ \\
\hline \multirow{2}{*}{ Wald test } & $x^{2}$ & $1.0 \mathrm{e}+08$ & $7.6 e+06$ & $1.2 \mathrm{e}+08$ & $1.6 e+06$ & $4.3 e+06$ \\
\hline & $\mathrm{P}$-value & 0.0000 & 0.0000 & 0.0000 & 0.0000 & 0.0000 \\
\hline
\end{tabular}
this problem (Table 9), so the White corrections were applied.

Table 9. Test results for heteroscedasticity

\section{Analysis of Influence of Country-Specific Determinants on European SMB}

See results of the regression analysis in Table 10.

As we see in Table 9 hypothesis 1 is confirmed concerning a positive significant relation between the innovative development level and SMB performance which supports the importance of the research and development factor. However, one should pay attention to the coefficient of the GII variable. It is positive and significant at a $1 \%$ and $5 \%$ level, however, when the indicator increases by 1 point SME's return on assets grows by 0.0505 which cannot be considered a strong influence.

We also confirmed hypothesis 2 on a positive and significant relation of the legal environment factors, in particular: rule of law indicators from the comprehensive point of view (ROL) and from the point of view of borrowers' and creditor's rights (LRI) and SME performance efficiency.

The analysis showed that the corruption component represented as the CPI index is insignificant which refutes hypothesis 3 .

The public and cultural factor represented by the determinants which characterize successful entrepreneurs (CDI) revealed a positive and significant relation with SME performance efficiency, thus, confirming hypothesis 4 . But again we have to draw attention to the coefficient of the CDI variable which amounted to 0.0167 and is indicative of a relative power (here - weakness) of influence.

\begin{tabular}{|c|c|c|}
\hline ROL & $1.454^{* * *}$ & $-0.809^{* * *}$ \\
\hline & $(0.310)$ & $(0.256)$ \\
\hline \multirow[t]{2}{*}{ CPI } & 0.000445 & $-0.0319^{* * *}$ \\
\hline & $(0.00772)$ & $(0.00431)$ \\
\hline o.CDI & - & \\
\hline \multirow[t]{2}{*}{ LnEMP } & $0.692^{\star * *}$ & $-0.267^{\star * *}$ \\
\hline & $(0.0770)$ & $(0.0371)$ \\
\hline \multirow[t]{2}{*}{ DTA } & $-17.15^{\star \star *}$ & $-13.95^{\star * *}$ \\
\hline & $(0.278)$ & $(0.154)$ \\
\hline \multirow[t]{2}{*}{ CBS } & $-0.112^{\star * *}$ & $-0.142^{\star * *}$ \\
\hline & $(0.0157)$ & $(0.00948)$ \\
\hline \multirow[t]{2}{*}{ BCC } & $-0.196^{* * *}$ & $-0.182^{\star * *}$ \\
\hline & $(0.0372)$ & $(0.0339)$ \\
\hline \multirow[t]{2}{*}{ PCI } & $-5.631^{\star * *}$ & $-1.185^{\star * \star}$ \\
\hline & $(0.915)$ & $(0.316)$ \\
\hline \multirow[t]{2}{*}{ PSI } & $-0.300^{\star *}$ & $-0.547^{\star * *}$ \\
\hline & $(0.120)$ & $(0.0716)$ \\
\hline \multirow[t]{2}{*}{ CDI } & & $0.0167^{\star * *}$ \\
\hline & & $(0.00517)$ \\
\hline \multirow[t]{2}{*}{ Constant } & $11.56^{\star * *}$ & $14.75^{\star * *}$ \\
\hline & (1.145) & $(0.413)$ \\
\hline Observations & 272,560 & 272,560 \\
\hline$R^{2}$ & 0.075 & \\
\hline $\begin{array}{l}\text { Number of com- } \\
\text { panies }\end{array}$ & 54,512 & 54,512 \\
\hline
\end{tabular}

Table 10. Regression analysis results of the total sample of European SME

\begin{tabular}{lll} 
Variables & $\begin{array}{l}\text { Total sample } \\
(\mathrm{fe})\end{array}$ & $\begin{array}{l}\text { Total sample } \\
(\mathrm{re})\end{array}$ \\
\hline GII & $0.0505^{* * *}$ & $0.0288^{* * *}$ \\
\hdashline & $(0.0166)$ & $(0.0102)$ \\
\hline LRI & $0.144^{* * *}$ & $0.270^{* * *}$ \\
\hline & $(0.0375)$ & $(0.0173)$ \\
\hline
\end{tabular}

Standard errors in parentheses:

${ }^{\star * *} \mathrm{p}<0.01,{ }^{* *} \mathrm{p}<0.05,{ }^{*} \mathrm{p}<0.1$. 
The results of the relation between SME performance efficiency and macroeconomic business climate were unexpected. This relation is significant at a $1 \%$ and $5 \%$ level and negative. However, the obtained result complements and confirms hypothesis 6 described below. The relation with the macroeconomic environment will be described in detail when we study regions individually. In view of the aforesaid, hypothesis 5 is rejected from the macroeconomic point of view.

The result on the costs for business startup (CBS) showed that the lower the costs in a country the less SME's return on assets is.

The political factor of external influence is expressed in the model by means of indexes of political constraint (PCI) and political stability (PSI). Therein, PCI may be called an index which is indicative of the power characteristics and PSI is an index presenting manifestation of people's sentiment as a representation of the political component in the countries. A significant negative relation was revealed between the political environment level and SMB performance. This is indicative of the fact that for entrepreneurs investments in high political risk countries may be reasonable only if return on investment justifies the extra risk. So we confirm hypothesis 6 .

For the sake of the model completeness we included the variables of corporate determinants in it. Hypotheses 7 and 8 are confirmed for these variables. Analysis results showed a significant positive relation between SMB size and its profitability as well as a significant negative relation between financial leverage and SME's return on assets.

We analyzed separately the results of the regression analysis of SME's return on assets with GEI, PRI indicators. The choice between the random- and fixed-effects models was made on the basis of Breusch-Pagan and Haussmann tests. The results confirm a logically and intuitively realized relation between business success and political rights freedom (PRI). The governance efficiency indicator (GEI) turned out to be the distinctive one showing a significant and negative result. However, the coefficient of the variable amounted to 0.0024 . So, the obtained result may be explained by imperfection of the aggregate sample as long as there is no opportunity to take into consideration all SMB representatives in the countries chosen for the research.

Summing up the results obtained from the total sample we notice a positive influence of innovation, legal environment and public and cultural characteristics development on SMB performance. A negative relation was detected between performance efficiency and political environment, business climate (from the point of view of macroeconomic conditions and costs for business startup). The analysis results also showed absence of corruption influence on SMB in European countries all through the sample.

\section{Analysis of Influence of Country-Specific Determinants on SMB of Certain European Regions}

See the regression analysis results for countries from certain European regions in Table 11. The choice between the random- and fixed-effects models was made on the basis of Breusch-Pagan and Haussmann tests.

The analysis results confirm hypothesis 1 for all European regions except for Eastern Europe. In Eastern Europe the $\mathrm{CII}$ indicator is insignificant. The biggest coefficient of the variable is registered in the Northern Europe model, the smallest coefficient - in the Southern Europe model.

The situation with the legal environment indicator is not so definite as in the total sample. The hypothesis of a positive and significant relation of the rule of law from the comprehensive point of view (ROL) was confirmed only for Southern Europe. In the Western and Eastern regions this indicator is insignificant and in the Northern region it is even negative. The rule of law from the point of view of borrowers' and lenders' rights protection (LRI) showed a negative significant relation with SME performance efficiency in Northern and Eastern Europe. In the Western and Southern region this indicator was insignificant which in general is indicative of invalidity of hypothesis 2. Still the assumption that economically underdeveloped countries, having realized the importance of external financing for SME, introduce measures to improve legal protection of credit relations parties is confirmed. This is manifested in the obtained results.

Table 11. Regression analysis results of samples for European SME

\begin{tabular}{|l|l|l|l|l|l|l|l|l|}
\hline & North Eur & North Eur & West Eur & West Eur & South Eur & South Eur & East Eur & East Eur \\
\hline Variables & $(\mathrm{fe})$ & $(\mathrm{re})$ & $(\mathrm{fe})$ & $(\mathrm{re})$ & $(\mathrm{fe})$ & $(\mathrm{re})$ & $(\mathrm{fe})$ & $(\mathrm{re})$ \\
\hline GII & $0.370^{* * *}$ & $0.274^{* * *}$ & & & & & -0.0359 & $0.0865^{* * *}$ \\
\hline & $(0.0510)$ & $(0.0329)$ & & & & & $(0.0321)$ & $(0.0287)$ \\
\hline o.LRI & - & & - & & - & & - & \\
\hline ROL & $-6.64^{* * *}$ & $-6.867^{* * *}$ & 0.282 & -0.0258 & $8.690^{* * *}$ & $7.760^{* * *}$ & -0.531 & $-4.390^{* * *}$ \\
\hline & $(2.303)$ & $(0.588)$ & $(0.394)$ & $(0.388)$ & $(0.634)$ & $(0.573)$ & $(1.965)$ & $(1.132)$ \\
\hline
\end{tabular}




\begin{tabular}{|c|c|c|c|c|c|c|c|c|}
\hline & North Eur & North Eur & West Eur & West Eur & South Eur & South Eur & East Eur & East Eur \\
\hline o.CDI & - & & - & & - & & - & \\
\hline \multirow[t]{2}{*}{ LnEMP } & 0.195 & $-0.359^{* * *}$ & $0.624^{\star * \star}$ & $-0.652^{\star * *}$ & $0.645^{\star * *}$ & $0.102^{*}$ & $0.943^{* * *}$ & $-0.431^{* * *}$ \\
\hline & $(0.216)$ & $(0.0857)$ & $(0.162)$ & $(0.0745)$ & $(0.109)$ & $(0.0572)$ & $(0.141)$ & $(0.0744)$ \\
\hline \multirow[t]{2}{*}{ DTA } & $-19.01^{\star * *}$ & $-14.00^{* * *}$ & $-14.53^{\star * *}$ & $-11.44^{\star * *}$ & $-14.65^{\star * \star}$ & $-11.97^{\star * *}$ & $-18.19^{\star * *}$ & $-16.41^{\star * *}$ \\
\hline & $(0.607)$ & $(0.324)$ & $(0.481)$ & $(0.272)$ & $(0.456)$ & $(0.241)$ & $(0.515)$ & $(0.307)$ \\
\hline \multirow[t]{2}{*}{ CBS } & 0.122 & 0.139 & 0.0409 & $-0.0939^{* *}$ & $-0.0768^{\star * *}$ & $-0.211^{\star * \star}$ & $-0.0013^{\star *}$ & $-0.0855^{\star * *}$ \\
\hline & $(0.111)$ & $(0.109)$ & $(0.0815)$ & $(0.0395)$ & $(0.0200)$ & $(0.0173)$ & $(0.2633)$ & $(0.0230)$ \\
\hline \multirow[t]{2}{*}{$\mathrm{BCC}$} & $0.571^{\star * *}$ & $0.478^{\star * *}$ & -0.102 & $-0.106^{\star}$ & $-0.380^{\star * *}$ & $-0.508^{\star * *}$ & $-1.435^{\star \star \star}$ & $-1.670^{* * *}$ \\
\hline & $(0.0839)$ & $(0.0793)$ & $(0.0640)$ & $(0.0635)$ & $(0.0491)$ & $(0.0488)$ & $(0.141)$ & $(0.127)$ \\
\hline \multirow[t]{2}{*}{ PCI } & $-11.93^{\star}$ & $-10.70^{* * *}$ & 7.325 & $-3.474^{\star * *}$ & $-5.990^{\star * *}$ & -1.387 & $-12.79^{\star * *}$ & $-2.848^{* * *}$ \\
\hline & $(6.898)$ & $(3.325)$ & $(6.060)$ & $(0.563)$ & $(1.181)$ & $(1.070)$ & $(1.578)$ & $(0.830)$ \\
\hline \multirow[t]{2}{*}{ PSI } & $-0.890^{\star *}$ & $-1.917^{\star * *}$ & $-0.496^{\star *}$ & $-0.479^{\star *}$ & $4.900^{\star * *}$ & $3.093^{\star * *}$ & $-0.842^{\star * *}$ & $-1.129^{* * *}$ \\
\hline & $(0.427)$ & $(0.348)$ & $(0.207)$ & $(0.196)$ & $(0.252)$ & $(0.173)$ & $(0.205)$ & $(0.154)$ \\
\hline \multirow[t]{2}{*}{ LRI } & & $-0.663^{\star * \star}$ & & -0.0788 & & 0.0359 & & $-0.129^{* * *}$ \\
\hline & & $(0.163)$ & & $(0.0981)$ & & $(0.0497)$ & & $(0.0420)$ \\
\hline \multirow[t]{2}{*}{ CDI } & & $-0.110^{\star * *}$ & & 0.0316 & & $0.200^{\star * *}$ & & 0.0197 \\
\hline & & $(0.0283)$ & & $(0.0246)$ & & $(0.0137)$ & & $(0.0165)$ \\
\hline \multirow[t]{2}{*}{ CPI } & & & $0.163^{\star * *}$ & $0.105^{\star * *}$ & $0.101^{\star \star \star}$ & $0.0279^{* * *}$ & & \\
\hline & & & $(0.0259)$ & $(0.0179)$ & $(0.00961)$ & $(0.00781)$ & & \\
\hline \multirow[t]{2}{*}{ Constant } & $9.045^{\star *}$ & $20.91^{\star * \star}$ & -0.874 & $7.099^{* * *}$ & 0.749 & $-2.467^{\star * *}$ & $21.42^{\star * *}$ & $19.29^{* * *}$ \\
\hline & $(4.590)$ & $(3.256)$ & $(4.827)$ & $(1.356)$ & $(0.825)$ & $(0.735)$ & $(1.546)$ & $(1.085)$ \\
\hline Observations & 69,875 & 69,875 & 61,815 & 61,815 & 68,120 & 68,120 & 72,835 & 72,835 \\
\hline$R^{2}$ & 0.067 & & 0.068 & & 0.099 & & 0.094 & \\
\hline $\begin{array}{l}\text { Number of } \\
\text { companies }\end{array}$ & 13,975 & 13,975 & 12,363 & 12,363 & 13,624 & 13,624 & 14,567 & 14,567 \\
\hline
\end{tabular}

Standard errors in parentheses: ${ }^{* *} \mathrm{p}<0.01,{ }^{* *} \mathrm{p}<0.05,{ }^{*} \mathrm{p}<0.1$. 
As for influence of the corruption component the hypothesis on a significant negative relation between the corruption level and SMB performance was confirmed for the Western, Southern and Eastern regions. It is worth noting individually that positive values of coefficients are indicated in the presented results and it is indicative of the negative relation in virtue of the definition of the CPI index. The North Europe countries where this indicator is negative were an exception (which should not be approached with a critical eye because the difference between CPI values of the Northern region countries is small and all these CPI indicators are above the average on the general CPI scale), i.e. hypothesis 3 is rejected only for the northern countries. The results obtained for the public and cultural determinants indicator may be called contradicting. The hypothesis on a significant positive relation of this indicator and SME performance is discarded for Western and Eastern Europe (the CDI indicator is insignificant). For Southern Europe the hypothesis was confirmed while for Northern Europe it was rejected with an unexpected result of a negative significant relation between the entrepreneurial determinants characteristic of population and SME performance efficiency.

The results concerning business climate from the macroeconomic point of view were mixed. Hypothesis 5 of a positive significant relation of indicators (ROA and BCC) was confirmed only for Northern Europe. In the Western region the hypothesis was discarded due to insignificance of the indicator. In the Southern and Eastern regions the hypothesis was also discarded, however, a significant negative relation between indicators was detected. While on the subject of founding an enterprise in a country we can emphasize a positive relation between costs on business startup and SME's return on assets in Eastern and Southern Europe (when the costs grow return on assets increases). In the Northern and Western regions costs on business startup are not significant. The obtained results are indicative of the fact that often (in this paper it concerns the sample of SME for Southern and Eastern Europe) SMB exists "in spite of, not thanks to".

Hypothesis 6 which asserts that there is a significant negative relation between the political risk level in a country and SME performance efficiency is admitted for the Northern and Eastern regions. In Western Europe the hypothesis was confirmed only concerning the political stability when it is represented as "a manifestation of people's sentiment" and was discarded concerning "power determinants" (the PCI variable is insignificant). The situation is reverse with the Southern region (the PCI indicator is significant while the PSI indicator - insignificant).

The hypotheses related to company determinants were confirmed similarly to the general sample results. A significant positive relation between SMB size and profitability is pointed out in three regions out of four. In Northern Europe this indicator is insignificant. A significant negative relation between financial leverage and SME's return on assets was revealed in all European regions.

Thus, let us sum up the results for each region separately.

\section{Northern Europe}

The level of innovative and technological development (the strongest influence among all studied regions) and macroeconomic environment have a positive influence on SME performance in Northern Europe. Taking into consideration insignificance of costs for business startup for SME of this region and a positive influence of macroeconomic environment we can speak of a favourable business climate. It should be noted that Northern Europe is the only region with a positive influence of business climate among all analyzed regions. The negative influence on SME's return on assets was detected with legal and political environment. The result of corruption analysis which showed a positive relation with SME performance was quite surprising but, as noted above, all values of the corruption indicator among Northern European countries indicate its extremely low level (except for Latvia, however, where this indicator is above the average).

\section{Western Europe}

In this region innovative development has a positive impact on SME's return on assets. Corruption and political environment have an adverse effect on SME performance. Other considered external factors (in particular: costs of business startup and macroeconomic environment, legal environment, public and cultural differences and political environment as an aggregate of government agencies' characteristics) were insignificant.

\section{Southern Europe}

Innovative development, legal environment, manifestation of people's sentiments in politics and the public and cultural factor have a positive effect on small and medium enterprises of the Southern region. At the same time costs, macroeconomic environment, political environment (as a power characteristic feature) and corruption have a negative impact on SME of Southern Europe. As for costs of business startup it should be noted that the research results show the following relation: the more the costs the higher the SME's return on assets in the region.

\section{Eastern Europe}

Innovations and technology development, legal environment and the public and cultural factor have no influence of SME of this region. Business climate, political environment and corruption, in their turn, have a negative impact on SME's performance in the region. Costs of business startup, similar to the Southern region, have a positive relation with SMB return on assets in the region.

\section{Analysis of Influence of Country-Specific Determinants on Small and Medium Enterprises of Developed and Emerging European Countries}

See the analysis results in Table 12. Similar to the collected results presented earlier here the hypotheses related to corporate determinants (size of small and medium enterprises is related significantly and positively to return 
on assets of such enterprises while financial leverage has a significant and negative relation with this indicator) are confirmed.

The innovative development level is positive and significant for SMB of developed countries. For SME of emerging countries the GII indicator is insignificant which manifests absence of influence of the technology innovative development level on return on assets in these countries. Hypothesis 1 is confirmed for developed countries and rejected for emerging countries.

Influence of legal environment of developed countries is positive, but it is significant only at a $10 \%$ level. This indicator is considered in the research for emerging countries separately and it is insignificant. Thus, hypothesis 2 is confirmed for developed countries and is rejected for emerging countries. However, from the point of view of lenders' and borrowers' rights protection hypothesis 2 is confirmed in both cases. The indicator of a democratic regime (political rights index (PRI)) and civil liberties index are positive and significant in both samples.

A positive coefficient of the CPI predicated variable for developed countries is indicative of a negative relation between the corruption level and SMB profitability, which is not the case with emerging countries. This phenomenon may be substantiated by a poor performance of financial and legal institutions as well as by the formal and informal institutional structure of each country (confirmed earlier by Tonoyan, Strohmeyer, Habib, Perlitz, (2010)). Thus, hypothesis 3 is confirmed for developed countries and rejected for emerging countries.

Table 12. Regression analysis results of samples for SME of developed and emerging countries

\begin{tabular}{|c|c|c|c|c|}
\hline & $\begin{array}{l}\text { Developed } \\
\text { countries }\end{array}$ & $\begin{array}{l}\text { Developed } \\
\text { countries }\end{array}$ & $\begin{array}{l}\text { Emerging } \\
\text { countries }\end{array}$ & $\begin{array}{l}\text { Emerging } \\
\text { countries }\end{array}$ \\
\hline \multirow[t]{2}{*}{ GII } & $0.141^{\star * *}$ & $0.0698^{\star \star \star}$ & -0.0162 & 0.00549 \\
\hline & $(0.0208)$ & $(0.0126)$ & $(0.0575)$ & $(0.0496)$ \\
\hline \multirow[t]{2}{*}{$\mathrm{ROL}$} & $0.565^{\star}$ & $-1.028^{\star * *}$ & & \\
\hline & $(0.321)$ & $(0.251)$ & & \\
\hline \multirow[t]{2}{*}{ LRI } & $0.398^{\star * \star}$ & $0.271^{\star \star \star}$ & $0.427^{\star * *}$ & $-0.170^{\star * *}$ \\
\hline & $(0.0699)$ & $(0.0245)$ & $(0.0766)$ & $(0.0454)$ \\
\hline \multirow[t]{2}{*}{ CLI } & & & $0.322^{* * *}$ & $-0.0987^{\star * *}$ \\
\hline & & & $(0.0680)$ & $(0.0332)$ \\
\hline \multirow[t]{2}{*}{ PRI } & & & $0.203^{\star * *}$ & $0.141^{\star * \star}$ \\
\hline & & & $(0.0421)$ & $(0.0378)$ \\
\hline \multirow[t]{2}{*}{$\mathrm{CPI}$} & $0.0233^{\star * *}$ & $-0.0272^{\star * \star}$ & $-0.0653^{\star *}$ & $0.0410^{\star *}$ \\
\hline & $(0.00825)$ & $(0.00515)$ & $(0.0326)$ & $(0.0197)$ \\
\hline \multirow[t]{2}{*}{ CDI } & & 0.00545 & & $0.102^{* * *}$ \\
\hline & & $(0.00553)$ & & $(0.0245)$ \\
\hline \multirow[t]{2}{*}{ CBS } & $-0.0325^{\star *}$ & $-0.109^{* * *}$ & $-0.439^{* * *}$ & $-0.199^{\star * *}$ \\
\hline & $(0.0156)$ & $(0.0103)$ & $(0.0916)$ & $(0.0511)$ \\
\hline \multirow[t]{2}{*}{ BCC } & $0.129^{* * *}$ & -0.00547 & -0.327 & $-1.503^{\star \star \star}$ \\
\hline & $(0.0367)$ & $(0.0331)$ & $(0.205)$ & $(0.184)$ \\
\hline \multirow[t]{2}{*}{ PCI } & $10.12^{* * *}$ & 0.559 & $-4.603^{* *}$ & 0.162 \\
\hline & $(1.002)$ & $(0.381)$ & (1.902) & $(1.205)$ \\
\hline \multirow[t]{2}{*}{ PSI } & $0.574^{\star * \star}$ & 0.0281 & $-1.038^{\star \star \star}$ & $-1.437^{\star \star \star}$ \\
\hline & $(0.136)$ & $(0.0862)$ & $(0.245)$ & $(0.192)$ \\
\hline
\end{tabular}




\begin{tabular}{|c|c|c|c|c|}
\hline & $\begin{array}{l}\text { Developed } \\
\text { countries }\end{array}$ & $\begin{array}{l}\text { Developed } \\
\text { countries }\end{array}$ & $\begin{array}{l}\text { Emerging } \\
\text { countries }\end{array}$ & $\begin{array}{l}\text { Emerging } \\
\text { countries }\end{array}$ \\
\hline \multirow[t]{2}{*}{ LnEMP } & $0.424^{* * *}$ & $-0.238^{* * *}$ & $1.022^{* * *}$ & $-0.392^{\star * *}$ \\
\hline & $(0.0823)$ & $(0.0385)$ & $(0.166)$ & $(0.0925)$ \\
\hline \multirow[t]{2}{*}{ DTA } & $-16.03^{\star * *}$ & $-12.43^{\star * *}$ & $-19.63^{\star * \star}$ & $-17.78^{\star * \star}$ \\
\hline & $(0.307)$ & $(0.162)$ & $(0.566)$ & $(0.347)$ \\
\hline \multirow[t]{2}{*}{ GEI } & $-0.0623^{* * *}$ & $-0.00804^{* * *}$ & $-0.122^{\star * *}$ & $-0.0529^{\star * *}$ \\
\hline & $(0.00855)$ & $(0.00298)$ & $(0.0219)$ & $(0.0167)$ \\
\hline o.CDI & - & & - & \\
\hline \multirow[t]{2}{*}{ Constant } & 0.885 & $11.12^{\star * *}$ & 5.822 & $18.54^{\star * *}$ \\
\hline & $(1.372)$ & $(0.540)$ & $(3.755)$ & (1.970) \\
\hline Observations & 218,785 & 218,785 & 53,775 & 53,775 \\
\hline$R^{2}$ & 0.066 & & 0.107 & \\
\hline $\begin{array}{l}\text { Number of } \\
\text { companies }\end{array}$ & 43,757 & 43,757 & 10,755 & 10,755 \\
\hline
\end{tabular}

Standard errors in parentheses:

${ }^{* * *} \mathrm{p}<0.01,{ }^{* *} \mathrm{p}<0.05,{ }^{*} \mathrm{p}<0.1$.

The public and cultural factor turned out to be positive and it is significant for SME of emerging countries. For developed countries this indicator is insignificant.

Costs of business startup are of great significance for SME of emerging countries, however, in developed countries a negative (in its essence the relation is positive) significant relation between this indicator and SMB profitability was identified. Macroeconomic business climate is significant and positive for SME of developed countries (which disproves of hypothesis 5) and it is insignificant of entrepreneurs from emerging countries.

Analysis of influence of political stability in the countries confirmed the assumption that small business in emerging countries exists "in spite of". So, in developed countries the PCI and PSI indicators are related positively to SME profitability which is opposite to the results for SME of emerging countries (hypothesis 6).

The result concerning influence of the government machinery efficiency and SMB profitability was controversial. A negative significant relation of indicators in both samples was obtained.

Analysis of Influence of Country-Specific Determinants on Innovative Small and Medium Enterprises of European Countries

Table 13 states results of the regression analysis of the total sample of innovative SME and Table 14 - results of the regression analysis of innovative SME of European regions.

The results of the regression analysis of the total sample of innovative small and medium enterprises manifest effi- ciency of the policy of innovative SMEs' support implemented by the government which is manifested through a positive significant influence of the governance efficiency on SME's return on assets. However, it should be noted that this indicator is significant only at a $10 \%$ level.

Table 13. Results of the regression analysis of the total sample of European innovative SME

\begin{tabular}{|c|c|c|}
\hline Variables & $\begin{array}{l}\text { Total sample } \\
\text { (fe) }\end{array}$ & $\begin{array}{l}\text { Total sample } \\
\text { (re) }\end{array}$ \\
\hline \multirow[t]{2}{*}{ LnEMP } & 0.360 & $-0.402^{\star \star}$ \\
\hline & $(0.285)$ & $(0.174)$ \\
\hline \multirow[t]{2}{*}{ DTA } & $-13.89^{\star * *}$ & $-12.46^{\star * *}$ \\
\hline & $(0.732)$ & $(0.548)$ \\
\hline \multirow[t]{2}{*}{ CPI } & 0.0337 & $-0.0392^{\star}$ \\
\hline & $(0.0398)$ & $(0.0228)$ \\
\hline \multirow[t]{2}{*}{ GII } & 0.0258 & -0.00139 \\
\hline & $(0.0849)$ & $(0.0540)$ \\
\hline \multirow[t]{2}{*}{ ROL } & -0.475 & -1.538 \\
\hline & (1.652) & $(1.290)$ \\
\hline
\end{tabular}




\begin{tabular}{|c|c|c|}
\hline Variables & $\begin{array}{l}\text { Total sample } \\
\text { (fe) }\end{array}$ & $\begin{array}{l}\text { Total sample } \\
\text { (re) }\end{array}$ \\
\hline \multirow[t]{2}{*}{ LRI } & -0.262 & $0.180^{*}$ \\
\hline & $(0.171)$ & $(0.0925)$ \\
\hline \multirow[t]{2}{*}{ PSI } & -0.595 & $-0.919^{* *}$ \\
\hline & $(0.621)$ & $(0.408)$ \\
\hline \multirow[t]{2}{*}{ GEI } & $0.0807^{*}$ & -0.0111 \\
\hline & $(0.0440)$ & $(0.0195)$ \\
\hline \multirow[t]{2}{*}{ PCI } & -0.282 & $2.898^{\star}$ \\
\hline & $(4.507)$ & $(1.647)$ \\
\hline o.CDI & - & \\
\hline \multirow[t]{2}{*}{ CBS } & $-0.204^{\star *}$ & $-0.231^{\star * *}$ \\
\hline & $(0.0906)$ & $(0.0514)$ \\
\hline \multirow[t]{2}{*}{ BCC } & 0.155 & 0.187 \\
\hline & $(0.191)$ & $(0.174)$ \\
\hline CDI & & $0.0861^{* * *}$ \\
\hline
\end{tabular}

\begin{tabular}{|c|c|c|}
\hline Variables & $\begin{array}{l}\text { Total sample } \\
\text { (fe) }\end{array}$ & $\begin{array}{l}\text { Total sample } \\
\text { (re) }\end{array}$ \\
\hline \multirow[t]{2}{*}{ Constant } & 5.924 & $15.25^{\star \star \star}$ \\
\hline & $(5.752)$ & $(2.217)$ \\
\hline Observations & 8,920 & 8,920 \\
\hline$R^{2}$ & 0.051 & \\
\hline $\begin{array}{l}\text { Number of } \\
\text { companies }\end{array}$ & 1,784 & 1,784 \\
\hline
\end{tabular}

Standard errors in parentheses:

${ }^{* * *} \mathrm{p}<0.01,{ }^{* *} \mathrm{p}<0.05,{ }^{*} \mathrm{p}<0.1$.

One of the hypotheses related to corporate determinants, namely, a negative significant relation between financial leverage and innovative SME performance was confirmed. The public and cultural factor is defined as a significant one in influence on performance efficiency of European innovative SME.

As a result of the research also a significant positive influence of costs (in its essence) of business startup on SME performance was found out.

Considering the results of Table 13 one can note that in all samples financial leverage has a negative significant influence on SME's return on assets, thus confirming one of the hypotheses on corporate determinants.

Table 14. Results of the regression analysis of the total sample of innovative SME of certain European regions

\begin{tabular}{|c|c|c|c|c|}
\hline Variables & $\begin{array}{l}\text { North Eur } \\
\text { (re) }\end{array}$ & $\begin{array}{l}\text { West Eur } \\
\text { (re) }\end{array}$ & $\begin{array}{l}\text { South Eur } \\
\text { (re) }\end{array}$ & $\begin{array}{l}\text { East Eur } \\
\text { (re) }\end{array}$ \\
\hline \multirow[t]{2}{*}{ LnEMP } & 0.100 & -0.532 & 0.761 & -0.184 \\
\hline & $(0.509)$ & $(0.354)$ & $(0.463)$ & $(0.382)$ \\
\hline \multirow[t]{2}{*}{ DTA } & $-12.77^{\star * *}$ & $-11.54^{\star \star \star}$ & $-14.45^{\star * *}$ & $-10.33^{* * *}$ \\
\hline & (1.645) & $(1.261)$ & $(1.391)$ & $(1.314)$ \\
\hline \multirow[t]{2}{*}{ GII } & & 0.179 & & \\
\hline & & $(0.127)$ & & \\
\hline \multirow[t]{2}{*}{$\mathrm{ROL}$} & $1.09^{* * *}$ & -1.031 & 4.536 & 2.458 \\
\hline & $(4.394)$ & $(1.803)$ & $(3.957)$ & $(8.008)$ \\
\hline \multirow[t]{2}{*}{ LRI } & -1.363 & -0.697 & -0.00765 & $-0.553^{* *}$ \\
\hline & $(1.079)$ & $(0.536)$ & $(0.393)$ & $(0.235)$ \\
\hline \multirow[t]{2}{*}{ PSI } & -2.010 & $-1.705^{\star \star}$ & 0.401 & -0.979 \\
\hline & (2.017) & $(0.826)$ & $(1.265)$ & $(0.920)$ \\
\hline
\end{tabular}




\begin{tabular}{|c|c|c|c|c|}
\hline Variables & $\begin{array}{l}\text { North Eur } \\
\text { (re) }\end{array}$ & $\begin{array}{l}\text { West Eur } \\
\text { (re) }\end{array}$ & $\begin{array}{l}\text { South Eur } \\
\text { (re) }\end{array}$ & $\begin{array}{l}\text { East Eur } \\
\text { (re) }\end{array}$ \\
\hline \multirow[t]{2}{*}{ GEI } & & 0.0346 & & \\
\hline & & $(0.0287)$ & & \\
\hline \multirow[t]{2}{*}{ PCI } & 13.70 & 3.797 & -2.377 & -2.681 \\
\hline & (23.78) & (2.679) & $(6.906)$ & (3.847) \\
\hline \multirow[t]{2}{*}{ CBS } & 0.0552 & 0.0340 & -0.231 & -0.154 \\
\hline & $(0.454)$ & $(0.143)$ & $(0.155)$ & $(0.1000)$ \\
\hline \multirow[t]{2}{*}{ BCC } & 0.625 & -0.0393 & $-0.781^{* *}$ & $-1.500^{* *}$ \\
\hline & $(0.434)$ & $(0.297)$ & $(0.320)$ & $(0.679)$ \\
\hline \multirow[t]{2}{*}{ CDI } & 0.151 & & $0.293^{* * *}$ & 0.102 \\
\hline & $(0.173)$ & & $(0.107)$ & $(0.0803)$ \\
\hline \multirow[t]{2}{*}{ CPI } & & & 0.0668 & 0.0135 \\
\hline & & & $(0.0457)$ & $(0.0852)$ \\
\hline \multirow[t]{2}{*}{ Constant } & 21.20 & 4.730 & -4.756 & $14.90^{* * *}$ \\
\hline & $(22.57)$ & $(8.717)$ & $(4.419)$ & $(4.961)$ \\
\hline Observations & 2,655 & 3,025 & 1,715 & 1,580 \\
\hline $\begin{array}{l}\text { Number of compa- } \\
\text { nies }\end{array}$ & 533 & 605 & 343 & 316 \\
\hline
\end{tabular}

Standard errors in parentheses:

${ }^{* * *} \mathrm{p}<0.01,{ }^{* *} \mathrm{p}<0.05,{ }^{*} \mathrm{p}<0.1$.

\section{Northern region}

The only significant indicator in the general model of the region is rule of law. Separately performed regressions for the indicators not included in the total sample allow to make the conclusion that the innovative development level has a positive impact on SME performance in the sample. This is not the case with government machinery efficiency and corruption. The obtained results are indicative of the necessity to go on improving the work of government authorities on SME support programs and of a positive influence of corruption on innovative SME performance.

\section{Western region}

A negative significant relation between political stability from the point of view of manifestation of people's sentiment (PSI) and performance efficiency of innovative SME (hypothesis 6 is confirmed) is revealed in the principal sample model. The regressions verified separately with corruption indicators and the public and cultural factor showed an insignificant result.

\section{Southern region}

Analysis of the principal model confirms hypothesis 4 on a positive influence of the public and cultural factor on success of innovative SME and also rejects hypothesis 5 because a negative relation between macroeconomic environment and return on assets of the SME from the sample was revealed. A separate analysis of regressions with the variables not included in the general model showed absence of influence of the country innovative development level and a positive influence of government machinery efficiency.

\section{Eastern region}

The principal model of this region showed a significant negative relation of return on assets of SME from the sample with rule of law from the point of view of credit relations and macroeconomic environment. The influence of government authorities efficiency and country innovative development considered separately is insignificant. 


\section{Conclusion}

In this paper we present analysis of influence of country-specific determinants on corporate performance. The subject of research is SMB from 24 European countries.

According to the review of available literature and various mass media sources we detected dependencies between certain external environment factors and corporate performance which formed the basis for the eight hypotheses suggested in the research (six of them consider influence of external factors).

The research samples were compiled on the basis of the Forbes rating Best Countries for Business, geographical division of Europe into regions made by the United Nations Statistics Division and the criteria established by the European Commission for defining SMB. 54,512 small and medium enterprises were analyzed in the paper. The total number of observations amounted to 272,560 unique values. The Amadeus database (Bureau Van Dijk) was used to collect data.

The empiric part of the research is represented by the regression analysis of panel data applying fixed-effects models as the main ones and random-effects models due to presence of time-constant variables. The used time period is 2013-2017. The regressions comprised the following variables - corporate determinants often used in papers: return on assets (ROA), company size (number of employees) (LnEMP), financial leverage (DTA). The distinctive feature of the research is use of indexes as a manifestation of external influence factors - country-specific determinants.

On the basis of the results of the regression analysis we considered the suggested hypotheses on influence of the innovative development level, corruption, legal environment, political factors, business climate and public and cultural determinants on performance of small and medium enterprises. The results for all 24 European countries in the sample are indicative of a positive influence of development of innovation, legal environment and public and cultural determinants on SMB performance. Political environment and business climate have a negative impact on SME performance. Corruption was insignificant for SMB in Europe.

Considering regional analysis results we can emphasize their similarity to the conclusions of the Forbes rating Best Countries for Business concerning the Northern region of Europe as the most favourable area for SMB startup and operation and concerning the Eastern region of Europe as the least favourable in this respect. The Western region showed to a greater extent SME nonsusceptibility to the indirect factors considered in the conducted research. There is no straightforward assessment of the Southern region because its countries are located in a random way.

The results as regards indicators of business climate, political environment and governance efficiency are indicative of the reality where SMB exists "in spite of, not thanks to", except for the countries of the Northern region where a negative influence is registered only for the governance efficiency indicator. However, the indicator of credit relations protection manifests a positive trend in the national policy of the countries where SME's return on assets is lower.

From the point of view of developed and emerging countries interesting results were obtained. So, innovation and legal environment turned out to be insignificant for emerging countries and significant - for developed ones. A weak significant positive relation of corruption and SME's return on assets of emerging countries in the sample was revealed as a result of the research. Costs of business startup have a positive effect on SME of developed and emerging countries. Therein macroeconomic climate and political environment have a positive impact on SME's return on assets in developed countries while in emerging countries this influence is negative.

According to the research results the innovative SMB of Europe was susceptible to costs of business startup (a positive relation) and government authorities efficiency (a positive relation). The results are indicative of a positive influence of public and cultural characteristics on performance of these SME. Additional calculations also showed a positive influence of the democratic regime, economic freedom and civil liberties on return on assets of innovative small and medium enterprises.

When studying the research results on regional distinctive features of external factors' influence on innovative SME a negative relation with business climate of enterprises in the Southern and Eastern regions should be noted. The level of country innovative development is significant only for innovative SME of the Northern region. Government efficiency has a positive impact on SME of the Southern region and a negative impact on SME of the Northern region. According to the research results, the corruption component has a positive effect on innovative companies of the Northern region and remains insignificant in other regions. The public and cultural factor is significant only for the Southern region and has a positive effect on return on assets of innovative SME of this region.

In spite of the fact that the goals of this paper have been achieved there is still a series of fields which need further research. Thus, the issue of influence of direct external factors on performance of small and medium enterprises is still unresolved. Due to insufficiency of data in publicly available sources this topic is left unaddressed and earlier papers confirm it.

\section{References}

1. De Jong, Abe, Nguyen, Thuy Thu, Kabir, Rezaul. "Capital Structure Around the World: The Roles of Firm- and Country-Specific Determinants" Journal of Banking and Finance, vol. 32, no. 9, (2008). 
2. Jõeveer, Karin. "Firm, country and macroeconomic determinants of capital structure: Evidence from transition economies". Journal of Comparative Economics, Elsevier, vol. 41 no.1 (2013) 294-308.

3. Koralun-Bereźnicka J. “On the Relative Importance of Corporate Working Capital Determinants : Findings from the EU Countries". Contemporary Economics, 8(4) (2014): 415-434.

4. Covin J. G., Slevin D. P. "Strategic management of small firms in hostile and benign environments." Strategic Management Journal, 10(1) (1989): 75-87.

5. Rauch A., Frese M. "A contingency approach to small scale business success: A longitudinal study on the effects of environmental hostility and uncertainty on the relationship of planning and success." Frontiers of Entrepreneurship Research (1998): 190-200.

6. Dobbs, M., \& Hamilton R. "Small business growth: Recent evidence and new directions". International Journal of Entrepreneurial Behaviour \& Research, 13(5) (2007): 296-322.

7. Simpson M., Padmore J., Newman N. “Towards a new model of success and performance in SMEs." International Journal of Entrepreneurial Behavior \& Research, 18(3), (2012): 264-285.

8. Sinitsyna E.D., "Sravnitel'nyi analiz effektivnosti nalogovykh i byudzhetnykh mer podderzhki malogo predprinimatel'stva $v$ Rossii” Vestnik VolGU. 9, no. 15 (2017): 138-145. (In Russ.).

9. Global Entrepreneurship Monitor. Global Report 2016/17. Global Entrepreneurship Research Association (GERA), 2017

10. Global Entrepreneurship Monitor Adult Population Survey. URL: https://www.gemconsortium.org/data/ sets (дата обращения: 20.01.2019)

11. Podtserob M. «S 2014 goda uroven' predprinimatel'skoi aktivnosti vyros v Rossii na tret' - GEM ». 2017 URL: https://www.vedomosti.ru/ management/articles/2017/02/07/676449-urovenpredprinimatelskoi-aktivnosti (дата оборащения: 13.03.2019) (In Russ.).

12. World Bank «Ease of Doing Business». URL: $\underline{\text { http:// }}$ www.doingbusiness.org/en/rankings (дата обращения: 23.01.2019)

13. Konings J., Rizov M., Vandenbusschedet H. "Investment and financial constraints in transition economies: micro evidence from Poland, the Czech Republic, Bulgaria and Romania”. Economics Letters, 78, no. 2, (2003): 253-258.

14. Forbes «Best Countries for Business». URL:https:// www.forbes.com/best-countries-for-business/ list/\#tab:overall (дата обращения: 23.01.2019)
15. Mc Cahery J., Lopez de Silanes F., Schoenmaker D., Stanisic D. "The European Capital Markets Study: Estimating the Financing Gaps of SMEs", (2015)

16. Financing SMEs and Entrepreneurs 2018: An OECD Scoreboard, OECD Publishing, Paris. URL: http:// dx.doi.org/10.1787/fin sme ent-2018-en

17. (дата обращения: 23.01.2019).

18. OECD Studies on SME and Entrepreneurship, OECD Publishing, Paris. URL: http://dx.doi. org/10/1787/978926423907-en (дата обращения: 20.01.2019).

19. McCahery J. A. «Estimating the SME Financing Gap in Europe», 2018

20. Rupeika-Apoga R. «Financing in SMEs: Case of the Baltic States». Procedia - Social and Behavioral Sciences. vol. 150, no.15, (2014): 116-125.

21. Simpson M., Tuck N., Bellamy S. "Small business success factors: The role of education and training." Education and Training, 46(8/9), (2004): 481-491

22. Watson K., Hogarth-Scott S., Wilson N. "Small business start-ups: Success factors and support implications." International Journal of Entrepreneurial Behavior \& Research, 4(3) (1998): 217-238.

23. Khairullina D.R. "Faktory, opredelyayushchie razvitie malogo biznesa." Upravlenie ekonomicheskimi sistemami: elektronnyi nauchnyi zhurnal. 97, no.3 (2017): 4. (In Russ.).

24. Cooper A. C., Gimeno-Gascon F. J., Woo C. Y. "Initial human and financial capital as predictors of new venture performance." Journal of Business Venturing, 9(5) (1994): 371-395.

25. Russel D. "Model' dlya analiza raboty soveta direktorov: rol' vnutrennikh i vneshnikh funktsii nezavisimykh direktorov". Journal of Corporate Finance Research / Korporativnye Finansy 2, no.2, (2010): 110-124. (In Russ.).

26. Theriou G., Chatzoudes D., Matlay H. "Exploring the entrepreneurship-performance relationship: Evidence from Greek SMEs." Journal of Small Business and Enterprise Development, vol. 22 issue: 2, (2015): 352-375.

27. Meijaard, J., Brand, MJ. \& Mosselman, M., "Organizational structure and performance in dutch small firms" Small Business Economics. 25, 1, (2005): 83-96

28. Choueke R., Armstrong R. "Culture: A missing perspective on small-and medium-sized enterprise development?" International Journal of Entrepreneurial Behavior \& Research, 6(4), (2000): 227-238 
29. Stewart W. H., Roth P. L. Risk propensity differences between entrepreneurs and managers: A metaanalytic review. Journal of Applied Psychology, 86(1), (2001): 145-153.

30. Shirokova G.V., Bogatyreva K.A. “Vzaimosvyaz' predprinimatel'skoi orientatsii $i$ rezul'tatov deyatel'nost $i$ firmy: rezul'taty issledovaniya rossiiskikh firm malogo i srednego biznesa" // Vestn. S.-Peterb. un-ta. 8, no. 1. (2014): 3-27. (In Russ.).

31. Mueller S. L., Thomas A. S. "Culture and entrepreneurial potential: A nine country study of locus of control and innovativeness." Journal of Business Venturing,16(1), (2001): 51-75

32. Benzing C., Chu H. M., Kara O. "Entrepreneurs in Turkey: A factor analysis of motivations, success factors, and problems." Journal of Small Business Management, 47(1), (2009): 58-91.

33. Country comparison. Hofstede Insights. URL: https:// www.hofstede-insights.com/country-comparison/ russia/ (дата обращения: 13.03.19)

34. NG, Siew Imm, LIM, Xin Jean. Are Hofstede's and Schwartz's values frameworks equally predictive across contexts? [online]. vol.21, no.1, (2019): 33-47.

35. Rogoff E. G., Lee M. S., Suh D. C. "Who done it?" attributions by entrepreneurs and experts of the factors that cause and impede small business success." Journal of Small Business Management, 42(4), (2004): 364-376.

36. Halabi C. E., Lussier R. N. "A model for predicting small firm performance: Increasing the probability of entrepreneurial success in Chile." Journal of Small Business and Enterprise Development, 21(1), (2014): $4-25$

37. Karpak B., Topcu I. “Small medium manufacturing enterprises in Turkey: An analytic network process framework for prioritizing factors affecting success." International Journal of Production Economics, 125(1), (2010): 60-70.

38. Lampadarios E. "Critical success factors for SMEs: An empirical study in the UK chemical distribution industry." International Journal of Business and Management, 11(7), (2016): 67-82.

39. Shirokova G.V., Tsukanova T.V. "Vliyanie natsional'noi institutsional'noi sredy na stepen' internatsionalizatsii firm malogo i srednego biznesa iz stran s perekhodnymi ekonomikami" // Vestn. S.Peterb. un-ta. 8, no. 1. (2012): 26-51. (In Russ.).

40. Gerardo L. Munck, 2003. Measures of Democracy, Governance and Rule of Law: An Overview of Cross-National Data Sets. URL: http://siteresources. worldbank.org/EXTWBIGOVANTCOR/Resources/ Measuresofdemocracy.pdf (дата обращения: 27.02.19)
41. Vasilenok V.L.., Aleksashkina E.I. "Razvitie predprinimatel'stva i faktory, ego opredelyayushchie”. Science journal NRU ITMO. Seriya «Ekonomika i ekologicheskii menedzhme» 12, no.1 (2013): 8-9. (In Russ.).

42. Audretsch D.B., Mahmood T. "New-firm survival: New results using a hazard function", Review of Economics and Statistics vol. 77, (1995): 97-103

43. Gupta, Kartick. "Do economic and societal factors influence the financial performance of alternative energy firms?". Energy Economics, Elsevier, vol. 65, (2017): 172-182.

44. Perez-de-lema D.G., Hansen P., Madrid-Gujjarro A., Silva-Santos J.L.(2018) "Influence of the business environment in the dynamics of innovation and in the performance of SMEs". International Journal of Innovation Management. URL: https://www. worldscientific.com/doi/abs/10.1142/S1363919619500 440? journalCode=ijim (дата обращения: 17.03.2019)

45. Audretsch D.B. "New Firm Survival and the Technological Regime", Review of Economics and Statistics, 68, (1991): 520-526.

46. Agarwal R., Audretsch D.B. “Does Entry Size Matter? The Impact of the Life Cycle and Technology on Firm Survival" Journal of Industrial Economics, 49, (2001): 21-43.

47. Vu H., Tran T. Q., Nguyen T., Lim S. “Corruption, types of corruption and firm financial performance: New evidence from a transitional economy". Journal of Business Ethics, (2016): 1-12.

48. Safavian, Mehnaz S., Graham, Douglas H. "Corruption and Microenterprises in Russia". World Development, Elsevier, vol. 29(7) (2000): 1215-1224.

49. Tonoyan V., Strohmeyer R., Habib M., Perlitz M. "Corruption and entrepreneurship: how formal and informal institutions shape small firm behavior in transition and mature market economies", Entrepreneurship theory and practice 34 (5) (2010): 803-832.

50. Gladysheva A., Kishilova J. “Vliyanie politicheskikh svyazei i gosudarstvennoi sobstvennosti na deyatel'nost' firm v Rossii", Journal of Corporate Finance Research /Korporativnye Finansy. 12, no.1 (2018): 20-43. (In Russ.).

51. Hunady J. "Individual and institutional determinants of corruption in the EU countries: the problem of its tolerance." Economia Politica: Journal of Analytical and Institutional Economics, Springer; Fondazione Edison, vol. 34 no.1, (2017): 139-157

52. Sharma, Chandan \& Mitra, Arup."Corruption, governance and firm performance: Evidence from Indian enterprises". Journal of Policy Modeling, Elsevier, vol. 37(5) (2015): 835-851. 
53. Angulo-Ruiz F., Pergelova A. "The impact of government financial support on the performance of new firms: the role of competitive advantage as an intermediate outcome" Entrepreneurship \& Regional Development, 26(9-10), (2014): 663-705.

54. Borbas L. "Supporting SMEs in Central-Eastern Europe." Volume of Management, Enterprise and Benchmarking in the 21ST Century, (2014): 87 - 106

55. Berko L., Agota G. "Policy for Support of Small and Medium-size Enterprises in Hungary: The Case of the Central Region, Post-Communist Economies". Post-Communist Economies, vol. 15 no. 2 (2003): $243-257$.

56. Galbraith B., McAdam R., Woods J., McGowan T. "Putting policy into practice: an exploratory study of SME innovation support in a peripheral UK region", Entrepreneurship \& Regional Development (2017): $1-20$

57. Bergström F. "Capital subsidies and the performance of firms." Small business economics 14(3), (2000): 183-193.

58. Zhang H., Li L., Zhou D., Zhou, P. “Political connections, government subsidies and firm financial performance: Evidence from renewable energy manufacturing in China." 『Renewable Energy $\bigotimes, 63(2)$ (2014): 330-336.

59. Hansen H., Rand J., Tarp, F. “Enterprise growth and survival in Vietnam: does government support matter?" The Journal of Development Studies, 45(7), (2009): 1048-1069.

60. Majocchi A., Valle L. D., D’angelo A. "Internationalisation, culture distance and country characteristics: a Bayesian analysis of SMEs financial performance" Journal of Business Economics and Management, 16(2) (2013): 307-324.

61. Delener N., Farooq O., Bakhadirov M. “Is Innovation a Determinant for SME Performance? CrossCountry Analysis of the Economies of Former USSR Countries." Entrepreneurship in Transition Economies. Springer International Publishing (2017): 97-111.

62. Kwamena Minta Nyarku \& Stephen Oduro. "Examining the Effect of Corruption and Bureaucracy on SMEs Growth in the Kumasi Metropolis of Ghana". Universities, Entrepreneurship and Enterprise Development in Africa, German African University Partnership Platform for the Development of Entrepreneurs and Small/Medium Enterprises. (2017) URL: https://pub.h-brs.de/ frontdoor/deliver/index/docId/3425/file/GAUP_ Conference_Proceedings_2017_154.pdf

63. http://dx.doi.org/10.7819/rbgn.v0i0.3956. (дата обращения: 27.03.19)
64. Whittington G. "The profitability and size of United Kingdom companies, 1960-1974.” The Journal of Indus- trial Economics., 25(4) (1980): 334-352.

65. Hall M., Weiss L. "Firm size and profitability." Review of economics and statistics, 49, (1967): 319 - 331

66. Ramasamy B., Ong D., Yeung M. C. H. "Firm size, ownership and performance in the Malaysian palm oil industry." Asian Academy of Management Journal of Accounting and Finance., 1, (2005): 81 - 104

67. Gebreeyesus, M. (2009) Innovation and microenterprises growth in Ethiopia. UNUMERIT working papers, http: www.merit.unu.edu/ publications/wppdf/2009/wp2009-053.pdf. (дата обращения: 23.01.2019)

68. Modigliani F., Miller M. "Corporate income taxes and the cost of capital: A correction." American Economic Review 53, (1963): 433-443.

69. Myers S., Majluf N., "Corporate financing and investment decisions when firms have information that investors do not have." Journal of Financial Economics 13(2), (1984): 187-221

70. Degryse H., Goeij P., Kappert P. “The impact of firm and industry characteristics on small firms' capital structure.” Small Business Economics 38(4) (2012):431-447

71. Mateev M., Poutziouris P., Ivanov K. “On the determinants of SME capital structure in Central and Eastern Europe: A dynamic panel analysis.” Research in International Business and Finance 27(1) (2013): 28-51

72. Serrasqueiro Z., Nunes P. “The capital structure of Portuguese SMEs: Empirical evidence using Dynamic Panel Data." Transformation in Business \& Economics 10(1), (2011): 62-80.

73. Zdráhal I., Chmelíková G., Blažková I. "Sector-Wide and Country-Specific Drivers of Firm Performance in the Visegrad Group Dairy Industry", AGRIS on-line Papers in Economics and Informatics, vol. 10, no. 4 (2018): 89-100.

74. Sadeghi A. "Success factors of high-tech SMEs in Iran: A fuzzy MCDM approach.” The Journal of High Technology Management Research, 29(1), (2018): 71-87.

75. Kobrin S. J. "Political risk: a review and reconsideration." Journal of International Business Studies 10(1) (1979): 67-80.

76. Butler K. C., Domingo Castelo J. "A note on political risk and the required return on foreign direct investment." Journal of International Business 29(3) (1998): 599-607.

77. Henisz W. J. “The institutional environment for economic growth.” Economics and Politics 12(1) (2000): 1-31. 
78. Zahra, S. A., \& Garvis, D. M. (2000). International corporate entrepreneurship and firm performance: The moderating effect of international environmental hostility. Journal of Business Venturing, 15(5), 469492.

79. Andersen T. J. "Multinational risk and performance outcomes: effects of knowledge intensity and industry context." International Business Review 21(2), (2012): 239-252.

80. Click R. W. "Financial and political risks in US direct foreign investment." Journal of International Business Studies 36(5) (2005): 559-575

81. Golikova V., Kuznetsov B. “Suboptimal Size: Factors Preventing the Growth of Russian Small and Medium-Sized Enterprises". Foresight and STI Governance, National Research University Higher School of Economics, vol. 11(3) (2017): 83-93.

82. Thapa A. "Determinants of microenterprise performance in Nepal." Small Business Economics, vol. 45, issue 3, (2015): 581-594.

83. Dagmar Vávrová. «Approaches to the classification of high-tech companies from the negative and positive point of view». Perspectives of Business and Entrepreneurship Development in Digital Age. 16 (2017): 125 - 136 